\title{
WestVirginiaUniversity
}

THE RESEARCH REPOSITORY @ WVU

Graduate Theses, Dissertations, and Problem Reports

2014

\section{User-Generated Content and Television News}

Eva M. Buchman

West Virginia University

Follow this and additional works at: https://researchrepository.wvu.edu/etd

\section{Recommended Citation}

Buchman, Eva M., "User-Generated Content and Television News" (2014). Graduate Theses, Dissertations, and Problem Reports. 539.

https://researchrepository.wvu.edu/etd/539

This Thesis is protected by copyright and/or related rights. It has been brought to you by the The Research Repository @ WVU with permission from the rights-holder(s). You are free to use this Thesis in any way that is permitted by the copyright and related rights legislation that applies to your use. For other uses you must obtain permission from the rights-holder(s) directly, unless additional rights are indicated by a Creative Commons license in the record and/ or on the work itself. This Thesis has been accepted for inclusion in WVU Graduate Theses, Dissertations, and Problem Reports collection by an authorized administrator of The Research Repository @ WVU. For more information, please contact researchrepository@mail.wvu.edu. 


\title{
User-Generated Content and Television News
}

\author{
Eva M. Buchman
}

\author{
Thesis submitted \\ to the Perley Isaac Reed School of Journalism \\ at West Virginia University
}

\author{
in partial fulfillment of the requirements for the degree of \\ Master of Science in \\ Journalism
}

\author{
Rita F. Colistra, Ph.D., Chair \\ Rick Bebout, M.S. \\ Emily H. Corio, M.S. \\ Nicholas D. Bowman, Ph.D. \\ Department of Journalism \\ Morgantown, West Virginia \\ 2014
}

Keywords: user-generated content, television news, intermedia agenda setting

(C)2014

Eva M. Buchman

ALL RIGHTS RESERVED 


\section{Abstract \\ User-Generated Content and Television News \\ Eva M. Buchman}

The purpose of this master's thesis is to investigate the relationship between television news stations and user-generated content. With the technological growth our society has experienced over the last several years, user-generated content has become a popular way for television stations to gather news. This relationship was investigated through a national online survey of news directors/executive producers at television stations. Also studied were policies at television stations regarding the use of user-generated content, whether they are formal, written policies, or informal policies, to determine how user-generated content is integrated into television news broadcasts. Findings suggest that television news stations exercise extreme caution when determining if they're going to use user-generated content, and those cautions are taken because of concerns about accuracy and credibility. The findings also suggest that user-generated content is most often used in the morning and evening hours of news broadcasts produced during the week, rather than on weekends. The information gathered in this research helps to better understanding about the perceptions of user-generated content, and how those perceptions shape policies regarding its use at television stations across the country. 


\section{Table of Contents}

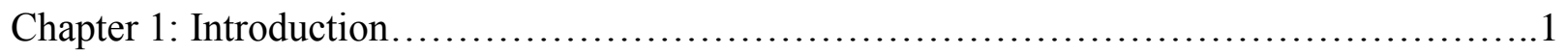

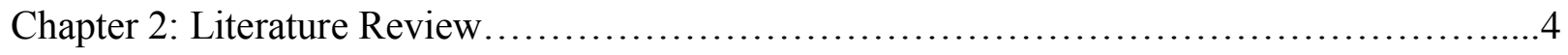

Roots of citizen journalism.................................................... 4

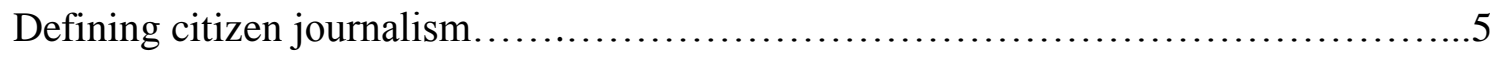

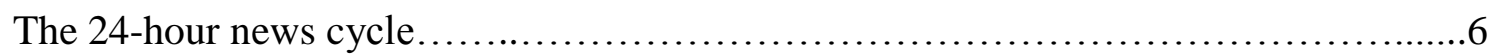

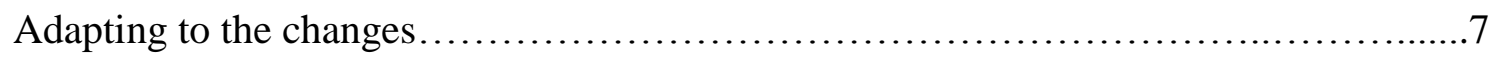

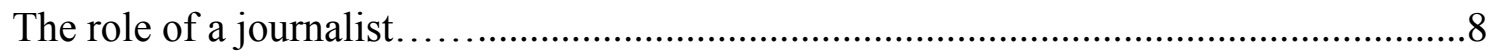

Skeptics of citizen journalism.................................................12

Current views of user-generated content............................................... 16

Importance of news and a well-informed society..............................................16

Public sphere.................................................................. 19

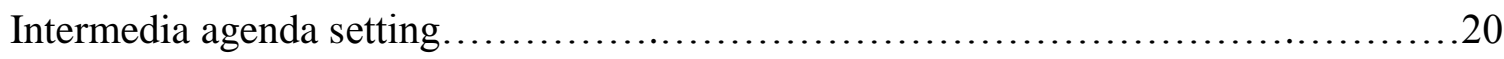

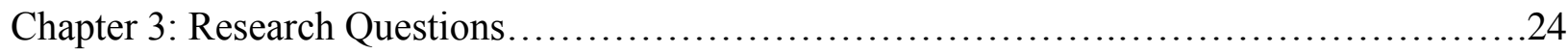

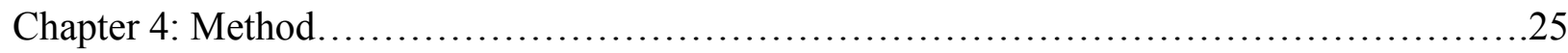

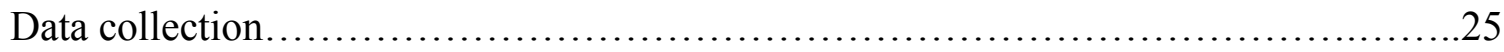

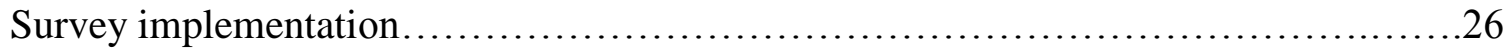

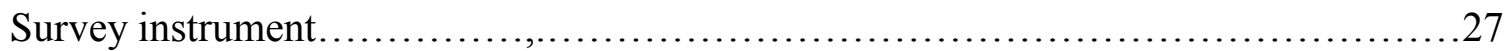

Variables.......................................................................... 30

Data analysis.......................................................................

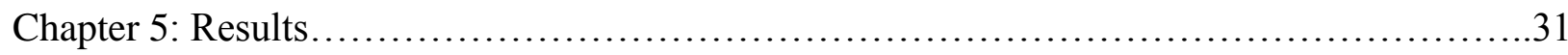

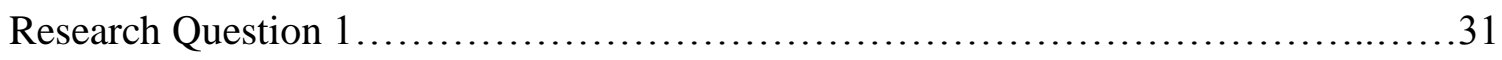

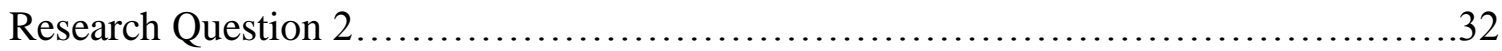

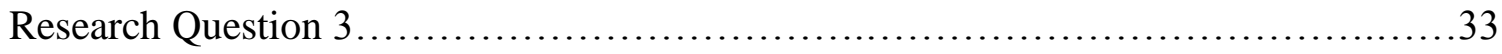




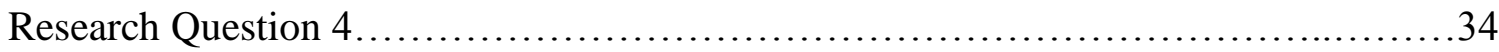

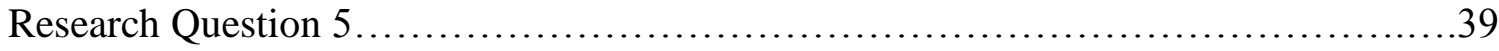

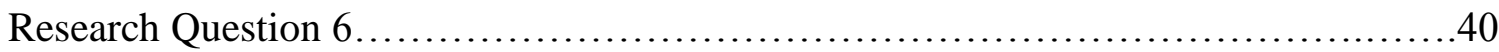

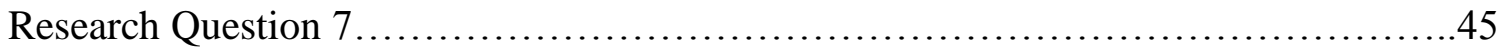

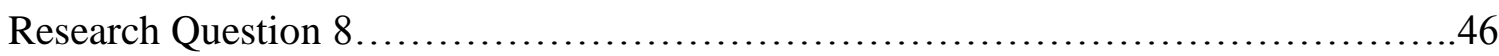

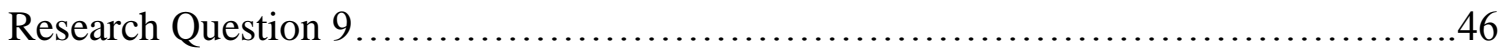

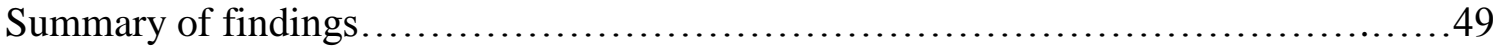

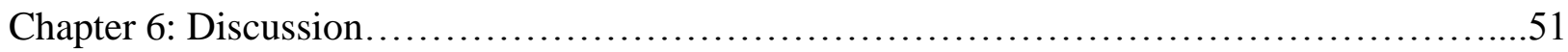

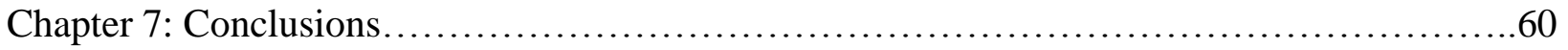

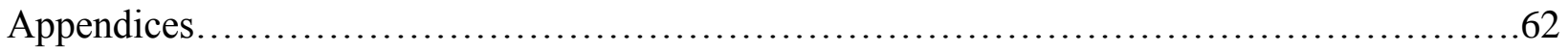

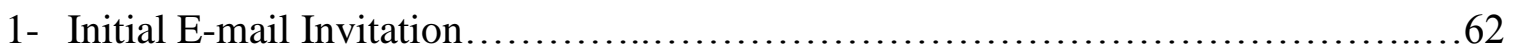

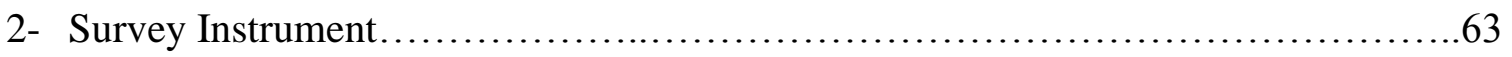

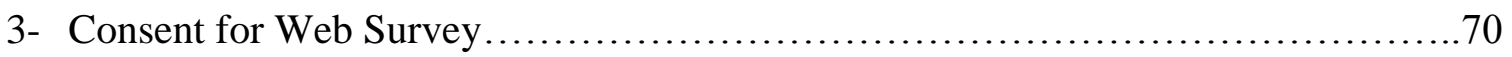

4- First E-mail Reminder Message.................................................... 72

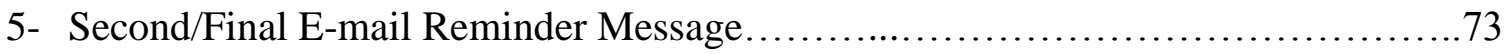

6- Table 1 Link between RQs and Survey Questions....................................74

7- Figure 1 Does your station have a formal policy in place? .............................75

8- Figure 2 Does your station have an informal policy in place?..............................75

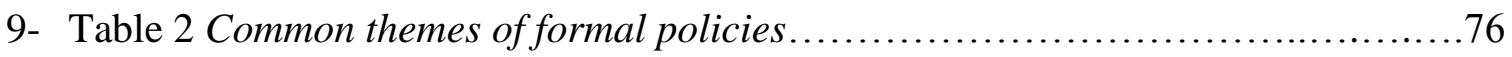

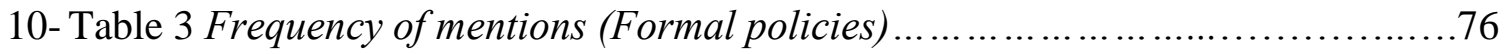

11- Table 4 Common themes of informal policies.......................................................

12- Table 5 Frequency of mentions (Informal policies)...........................................77

13- Table 6 How often is user-generated content used?...............................................78

14- Table 7 What reason was most cited for using user-generated content?......................79

15- Figure 3 What type of user-generated content is used most?.....................................80

16- Figure 4 Does your station encourage viewers to submit user-generated content?....80

17- Table 8 How does your station encourage viewers to submit UGC?..........................81

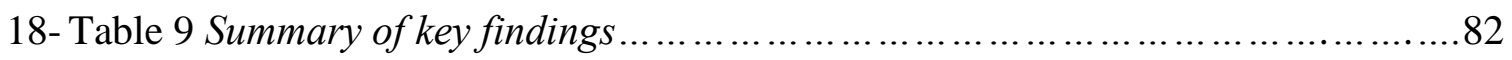

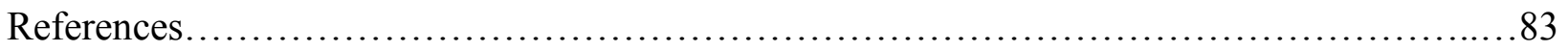




\section{Directory of Tables and Figures}

\section{$\underline{\text { Tables }}$}

Table 1 Link between Research Questions and Survey Questions..............................29

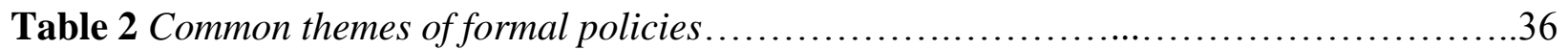

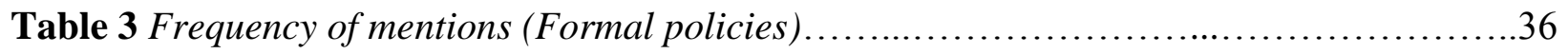

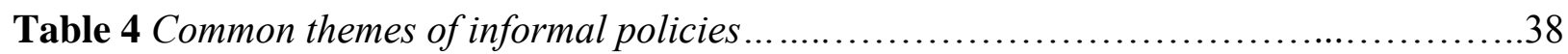

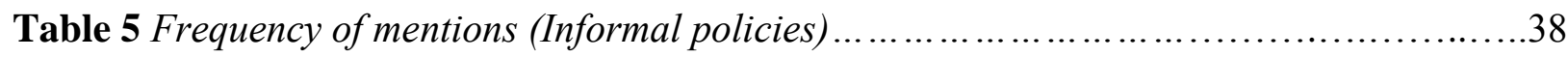

Table 6 How often is user-generated content used?...............................................................40

Table 7 What reasons were most cited for using user-generated content?..................................42

Table 8 How does your station encourage viewers to submit user-generated content?...............48

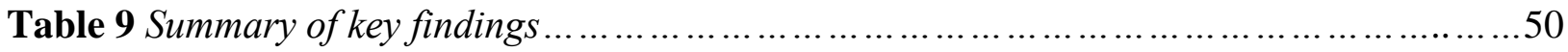

\section{Figures}

Figure 1 Does your station have a formal, written policy?...............................................33

Figure 2 Does your station have an informal policy?.........................................34

Figure 3 What type of user-generated content is most used?.....................................46

Figure 4 Does your station encourage viewers to submit user-generated content?................47 


\section{Chapter 1: Introduction}

The world of journalism has seen many transition phases, beginning with a shift from newspapers to radio, then from radio to television, and television to the Internet and mobile. Along with this latest shift, there has been an increased level of access granted to news consumers, as they can comment via social media, comments, and/or e-mails to express their opinions. Previously, news consumers only had phone calls and letters to their media sources. With the increase of technology in our society, viewers are constantly connected to the news and have control over the news they consume. They're now even becoming a part of the production process. The idea of citizen journalism, widely accepted to have been started after the events of September 11, 2001 (Gillmor, 2004), continues to grow rapidly, leaving traditional news outlets with no other options but to quickly adapt.

The argument can be made that user-generated content is aiding in the shifting of traditional journalism, but there are still many questions left unanswered about if, and how, it could be incorporated into traditional journalism. One major sticking point in this transition is the fact that there is not one universally accepted definition for user-generated content, and it seems everyone has a different idea of how it should utilized. One thing scholars like Dan Gillmor have been able to agree on, however, is that citizen journalism is transforming the media from a lecture to more of a conversation (Gillmor, 2004).

Scholars like O'Reilly discuss how 2001 was a turning point for the web, as it was the bursting of the dot com bubble. O'Reilly's thoughts suggest that people create value when they are engaged in activities on the internet (O'Reilly, 2011), bolstering the argument that different forms of media are allowing people to be more conversational. 
The idea that participation has become more prevalent is helpful because there are so many events going on that may be considered newsworthy. As a result, parts of communities could be segmented and feel distanced from their news outlets. Arguably one of the most important parts of being a journalist is effectively and truthfully telling a story, but, ultimately, not every news consumer is going to be happy because they cannot learn about all of the things that are important to them.

As noted by Lauterer (2000), news becomes more important to a community as it gets closer to that community. Local news has taken on a new identity now that citizens have the ability to report it from virtually anywhere. Technology is changing so rapidly, that it's nearly impossible to always be up to date. As Lauterer (2000) noted, "The hardware you bought last month is antique today; no sooner do you learn the latest version of a program than it becomes obsolete" (pg. 159). Contributing news online has certainly become a game-changer in the way news is reported. The impact of citizen journalism on a community can be substantial, if it is used in the most effective ways (Lauterer, 2000).

Fernando (2008) and Bentley (2006) would argue this is what opens the door for usergenerated content to fill a void. By gathering, producing, and helping to distribute the news they want to hear about, citizens help to bring communities back together. It is still important to understand that just because citizens are producing more news content than ever before by creating community websites, blogs, and by sending their stories and videos to different news outlets, it seems there is still no standard procedure for if, or how, news outlets should incorporate any user-generated content they may receive. 
One of the most widely known television outlets, CNN, has a program called the iReport, where citizens send in their first-hand photos and videos, which are vetted by CNN professionals before they ever reach the air or Internet (King, 2012). However, is this the case for smaller, local television stations?

The purpose of this research is to help explore news directors' feelings toward usergenerated content, and how those feelings shape policies regarding this type of content. For purposes of this research, user-generated content is defined as story ideas, photos, videos, audio or ideas to generate stories that are sent to a television station by an amateur viewer. By understanding if, or how, television stations incorporate user-generated content into their newscasts, it will help to define user-generated content, and perhaps help understand how perceptions shape policies. This study aims to investigate how user-generated content is integrated into a television broadcast, as well as what types of user-generated content are used most often. In other words, this research strongly seeks to learn if there is a standard procedure that is used by television stations, and how and why this type of content is integrated into television news broadcasts. 


\section{Chapter 2: Literature Review}

It is no secret that people have always had opinions, and they will continue to carry them throughout the future. Citizens have been participating in journalism for decades, but in a very different way than they do now. Even if news consumers did use letters and/or phone calls to provide their feedback to reporters, there was usually no telling how far it went within an organization and if it made any real difference in the way journalists reported on news within their communities. Although it was successful, traditional journalism could be considered a very one-sided communication style because there weren't as many options for feedback (i.e., no open second channel of communication). That is starting to rapidly change because news production, reproduction, and distribution are getting so easy. It's to the point where anyone with a smart phone can be a publisher, which opens the lines for two-way communication.

Shirky (2008) describes a conceptual idea behind broadcast journalism - that it is shaped like a megaphone. Broadcast amplifies one message to many receivers, but since there is not one specific recipient, there is not much two-way communication. The recipients couldn't talk back, but technological innovations like smart phones and social media apps are opening new channels of communication.

\section{Roots of citizen journalism}

In his book Mixed News: The public/civic/communitarian journalism debate, Editor Jay Black (1997) describes that the very beginnings of citizen journalism began to take hold after the 1988 presidential election between George H.W. Bush and Michael Dukakis. This election brought to light a widening gap between the press and the citizens by way of the lackluster reporting and the lack of facts that drove citizens to realize they wanted more from the press. 
According to Black (1997) "Not only did journalists cover the 1988 election as a race, a contest, but more than ever before journalists insisted on giving readers, viewers and listeners an 'insider's view' of politics...," which was thought of as irrelevant to the real issue at hand — the positions of the two political candidates (p. 123).

The 1988 Presidential election was the starting point of a much bigger revolution that would happen years later. Despite the success traditional journalism had in reaching specified target audiences, a new wave of journalism was becoming prevalent, and it forced traditional journalism to adapt to keep up.

With the increase in technology and access, citizens have more choices like where and when they get their news, and what type of news they want. News has become more focused, as we can filter out what we're not interested in and hone in only on the topics we're most interested in hearing about. This bodes well for citizen journalism because the whole idea behind this new type of journalism is that citizens can talk about the issues that are of importance to them. Now more than ever, citizens can aggregate their news in one place and can tailor it to their specific needs. Unquestionably on the rise, citizen journalism still has several questions surrounding it and the place it will ultimately fit in the world of traditional journalism.

\section{Defining citizen journalism}

One of those questions delves into the very core of citizen journalism: what is it? There is not one solid definition for citizen journalism that has been mutually agreed upon by everyone, leaving lingering questions in the balance. Each definition of citizen journalism has similarities, but every scholar approaches the idea differently. According to Johnson and Wiedenbeck (2009), “Citizen journalism is news content produced by ordinary citizens with no formal journalism 
training” (p. 333). More broadly, however, is a definition provided by Beaudry: "Civic journalism is about asking a new set of questions, engaging a community in problem solving by helping readers and viewers focus on, understand, and listen to their own and each other's solutions" (Beaudry, 1996, p. 26). These two definitions both take into consideration engaging the community and using content produced by amateur viewers to answer questions. Taking those definitions into account, for purposes of the current research, user-generated content will be defined as photos, videos, audio, or ideas to generate stories that are sent to a television news station by an amateur viewer.

\section{The 24-hour news cycle}

With the emergence of new technology, blogs, and increased citizen interest, the flow of information is also on the rise. We live in a $24 / 7$ news cycle where it is always possible to access news, and it is becoming increasingly common for citizens to produce news.

There is a large amount of work required to effectively and truthfully tell a story. This, combined with the number of newsworthy events happening in communities, makes a lot of work for trained journalists. The constant news cycle makes it possible for citizen journalists to cover the stories they want to hear about and that are pertinent to their communities. It also makes it possible for citizens to get noticed within their communities and to shed light on issues that may not have garnered the amount of desired attention. In a way, citizen journalism fills the void that has been created by the 24-hour news cycle (Angelo, 2008).

There has been much research conducted about the rise of citizen journalism and usergenerated content, and how traditional journalism outlets are essentially being left with no choice but to adapt to the changes (Nip, 2006). However, what is lacking is research that investigates 
what processes traditional news outlets use to determine if and how they are integrating usergenerated content into their own reports. This is where the current research steps in.

In the literature that does exist, one overarching theme has appeared: traditional news outlets, both broadcast and print, are being forced to adapt their news gathering, producing, and reporting to accommodate the influx of user-generated content (Gillmor, 2004).

\section{Adapting to the changes}

Gillmor (2004) places citizen journalism into historical context. He explains that in the 1940s, it was with radio that Walter Cronkite and Edward Murrow were able to deliver updates of World War II. In the 1960s, it was the tragic death of President John F. Kennedy that had people glued to their television sets. Within the last 15 years, one of the most notable events in our history occurred: the terrorist attacks of September 11, 2001. Many researchers of citizen journalism point to this event as where a rise in citizens producing content began-people were on the streets while this attack happened. They were able to physically see the damage first-hand, and ordinary citizens turned into heroes while they saved their neighbors in harm's way. The pain, both emotional and physical, is what still remains vivid in people's minds. Citizens were able to take pictures and videos with their cell phones, which quickly circulated, as well as get in touch with their friends and families to report their safety. Almost instantaneously, people outside of New York City knew what was happening before learning the specifics of why and how because of this user-generated content (Gillmor, 2004).

This one event almost instantly turned people into reporters; everyone in New York City had a story to tell and something to show. On this day, citizens-turned-reporters were making the first imprint on history. Grainy cell phone photos and videos were the first images the public saw 
of this horrific event, with the facts and information coming later. Although this event wasn't the first time citizen journalism and user-generated content came into play, it was perhaps the first time they reached a mass audience. Those particular factors are important to understand when looking at citizen journalism and user-generated content as a whole as well as how it is growing and being integrated into traditional journalism every day.

There have certainly been other events, one of which was discussed by Marshall (2005). For example, Hurricane Katrina reinforced the stronghold citizen journalism has taken because consumers are not as passive toward the news as they had been before (Marshall, 2005). He explains that stories, photos, and videos produced by citizens of New Orleans made their way to the websites of the local television stations and newspapers, as well as to media outlets like CNN and MSNBC (Marshall, 2005). Hurricane Katrina was another example of how citizens do not have to wait on trained professionals to gain access and interviews to report the news. In this instance, they made themselves a part of the team that was providing coverage of this catastrophic event.

\section{The role of a journalist}

As the shift in the type of journalism has progressed, the role of journalists has also changed. Journalism in and of itself is an ever-changing job, which makes it difficult to define. Some view journalism as a profession, while others would define it as a craft, more along the lines of a specialized task. There are four attributes that regularly define a profession, which include: (1) specialized knowledge; (2) public service over personal gain; (3) autonomy to practice specialized skills; and (4) self-regulation (Colistra, 2010). Defined by these attributes, journalism cannot be deemed a profession in the truest sense of the word, but it is looked at as a 
learned craft (Colistra, 2010). This means that journalists have extended training that separates them from the rest of the population.

In terms of journalism, professionals also become gatekeepers who control access to the information people receive, and how and when they receive it (Shirky, 2008). Previously, journalism had a fairly standardized structure. Reporters were assigned stories by an assignments editor or news director, went out and shot the stories, and then came back and edited them for the evening's news. The news director (or equivalent) was there to answer any questions and take part in any potential ethical debates.

Now, however, thanks to the development of Web 2.0 and citizen journalism, gatekeeping is more embedded in technology and is less strictly enforced than it had been previously (Shirky, 2008). Because the journalism ecosystem is changing so drastically and so quickly, it's taking some getting used to on behalf of news organizations, as they are finding themselves with less control than they've ever previously experienced.

The term gatekeeper was first applied by Kurt Lewin (White, 1964). The idea he described was that news traveling through communication channels was dependent on whether it could get through "gates" (Lewin, 1947). Essentially, "gatekeepers" are either an individual or a group that is "in power" for making the decision between "in" or "out" (pg. 145). Lewin (1947) continued to explain that before researchers could better understand the gatekeeping process, they needed to understand the factors that determine the decisions made. These factors can determine social processes that can influence the gatekeeper. This process can be subjective, with no clear right or wrong decision-making process. User-generated content goes through similar systems at television news stations, with policies, as well as news directors/executive 
producers acting as gatekeepers, deciding what pieces of user-generated content they'll accept and what pieces they'll reject.

White (1950) discussed that the process of choosing and discarding news is constantly changing, based on the gatekeepers personal experiences and attitudes. Having the final say on what stories run and what stories get discarded provides control; however, citizen journalism is changing this as well. White's study, while focused on print media, aimed to understand the general role of a gatekeeper in mass communications. White had a newspaper wire editor of a morning newspaper save all stories that crossed his desk - even those he rejected for print in the paper-and write why he rejected the stories he did. The findings indicated that oftentimes, choices made by the gatekeeper were actually made by gatekeepers in competing media. This finding lends itself to intermedia agenda setting, in that often the gatekeeper was found to print similar stories as other media outlets were printing. Though this study was print based, the ideas can be spread across all mass communication media.

Television operates in much the same way. "Big" stories usually start with a few stations reporting it, and then other stations catch on. Although not all user-generated content is used by the television news stations it is sent to, the choices of what to use can be difficult.

The content that gets used versus the content that is discarded is also largely dependent on the journalist/source relationship. Citizens can provide content that is cheaper to access and more feasible to obtain. Sometimes, citizen journalism can influence the news because of the ability it has to provide constant content, and in a breaking news situation, it could be the only source of information in the beginning (Shoemaker \& Reese, 1996). Shoemaker \& Reese also discuss how oftentimes the information provided to citizen journalists is used to shape the full 
story that is written later. Because there is no hard-and-fast rule for the use of user-generated content, there is a lot about the journalist/source relationship to still be understood.

Some argue that because journalists are always meeting new people and moving around, it is hard to develop and maintain steady relationships with community members. Mayer (2011) spoke to several journalists and asked if they feel they're working on behalf of their communities. She found that most journalists agreed that " 1 ) they're using information to improve their communities; 2) they want their community members to feel invested in and connected to the news product; and 3) they want as much information as they can get about what their readers want and need to know" (pg. 12).

Working on behalf of a community is what many believe to be at the core of journalism. As noted by the Society of Professional Journalists, "The American people must be well informed in order to make decisions regarding their lives, and their local and national communities" (“Our Mission", 1996, para. 1). SPJ works to promote the flow of information, encourage diversity, and to encourage a climate in which journalism can be practiced freely, while still maintaining high standards and ethical behavior (“Our Mission”, 1996, para. 4).

However, this task is not always as easy as it sounds. With the technological advances, it may be time to strive for a balanced relationship between traditional and citizen journalists. Journalists having a good relationship with the people in their communities, and vice versa, is important in terms of developing sources, a level of comfort, and a level of accountability. In an ideal world, journalists should want to "do right" by their communities and be a voice for those who aren't heard. However, this isn't always possible, which is what has allowed citizens themselves to step in and define their own roles within their communities. This new type of 
journalism is increasingly more transparent and has an added level of accountability, both of which have become even more important to modern society (De Keyser \& Raeymaeckers, 2012). Skeptics of citizen journalism and user-generated content

Not all media professionals are accepting of citizen journalism and user-generated content. For instance, Clark (2009) points to the idea that many traditional journalists view citizen journalism as a threat to their profession and almost an insult to the work they do. Clark, who is employed at the Poynter Institute of Journalism, claims "amateurism can become a dangerous substitute for trained, responsible behavior" (Clark, 2009, p. 2).

Clark's fear does not come without merit, as there have been several cases of mistaken identity that have gone viral and proven harmful to innocent people. Clark may argue that these problems would bolster the argument that a formal policy would be helpful in determining the use of user-generated content.

On April 15, 2013, during the oldest annual marathon in the United States, a series of bombs were detonated near the finish line of the Boston Marathon. Three people were killed and over 260 were injured, and thousands of lives were altered forever. In the vexing moments immediately following the blast, security photos began circulating the Internet and people were trying to identify those who could have been responsible for such an attack. Through surveillance video, a high school classmate of missing Brown University student Sunil Tripathi thought she recognized him in photos released by police.

Shortly after, Reddit users were comparing the security photo of Sunil to those they could find of him online, and they thought they had solved the case. Around 2:15 a.m., people listening to police scanners heard the police identify two possible suspects, and a Twitter user tweeted: "BPD has identified the names: Suspect 1: Mike Mulugeta. Suspect 2: Sunil Tripathi." 
This was all it took for the information to go viral in a matter of minutes and be picked up by a variety of news outlets, print, online, and television (Madrigal, 2013). What Reddit users didn't know at the time was that Tripathi had been missing since mid-March, and his body was discovered in the water of India Point Park in Rhode Island nearly two weeks after the Boston bombing. Reddit general manager Erik Martin issued an apology to the Tripathi family for what he called "dangerous speculation" that "spiraled into very negative consequences for innocent parties" (Stanglin, 2013).

Another example of a mistaken identity in the media is that of Adam and Ryan Lanza during the Sandy Hook Elementary School shooting in Newtown, Ct., on Dec. 14, 2012. As written by Kashmir Hill of Forbes (2012), the shooter was wrongly identified due to a mix of misinformation from law enforcement agencies and news outlets "racing to be first" (para. 1). Ryan Lanza's photo was shared thousands of times online and on other media outlets, and he was labeled as the shooter, when, in fact, he had been at work during the shooting. Ryan Lanza began posting Facebook statuses denouncing the accusation, while the police found his brother, and shooter, Adam Lanza, dead of a self-inflicted gunshot wound at the scene. It is reported that a police officer mixed up the brother's names when relaying the information, but the mistake was shared over 8,000 times on social media and picked up by CNN, Fox News, and other television and online sources.

Situations like these two are why Clark and others are still skeptical of how, or if, usergenerated content should be used at all. Although these are just two cases, they raise serious ethical issues that can affect many people. These recurring problems could cause some to feel that having a formal policy regarding the use of user-generated content at television news stations should be necessary. 
That being said, Clark acknowledges that citizen journalists, or "paraprofessionals," still have the potential to be helpful in a world of journalism because it is a field that does not require being a licensed professional to practice it. Although there is extra training that sets journalists apart from just anyone, there is no certification required, as there is for doctors or lawyers. Clark argues that "paraprofessionals" have an advantage because at any moment, they could be an eyewitness to news, and by helping professional journalists, they are doing their part to develop a stronger connection between the two groups.

Clark (2009) also brought to light a new idea that was unmentioned in other research articles - the idea of training amateur journalists so they understand the basic journalistic principles and integrities so their credibility is not in question. He describes the "pyramid of journalism competence," with the cornerstones being news judgment and solid evidence and the capstone being mission, ethics, and purpose (p. 3). By helping to train amateur journalists with these guiding principles, it would help them to grow their own skills and understanding. Not only that, but their credibility and reliability would also grow, increasing the chances of their work being utilized by traditional news outlets.

One of the main problems traditional journalists have had during the rise of citizen journalism is that they feel citizen journalists have no training, no credibility, and hardly any understanding of what is actually required of a journalist. According to Brown (2005), these feelings are still somewhat standing in the way of how traditional media outlets look at citizen journalism, and they could potentially play a significant role in how individual outlets choose to incorporate user-generated content into their own broadcasts and/or publications. This problem could directly relate to why there is little existing research regarding the use of user-generated content. 
Every news organization operates differently and, thus, has different opinions about how to best incorporate user-generated content. Although there are concerns about this type of content, it can be useful. News organizations may question the quality of the user-generated work because citizen journalists have little to no formal training. Motives for producing usergenerated content could also be seen as skeptical, as news organizations are still adjusting to how to use these pieces in their broadcasts (Wahl-Jorgensen, Williams \& Wardle, 2010).

As previously mentioned, Brown (2005) suggests that a lack of training for citizen journalists could be standing in the way of what makes broadcast outlets decide to incorporate user-generated content. This potential sense of incompetency or lack of understanding of what a traditional journalist does and certain journalism standards could deter broadcast stations away from welcoming user-generated content.

As noted by Feighery (2011), the idea of self-criticism is important because it reflects the willingness of professional journalists to examine their own processes and how those processes affect the way they report. This approach, Feighery says, causes journalists to look inside themselves and their work to investigate their news gathering and reporting conventions, and to see how those techniques are constrained by media owners, advertisers, and internal organizational pressures and expectations. This process can be quite the daunting task for journalists, as it requires responding to public needs while still trying to maintain positive relationships within their organizations and trying not to ostracize themselves from higher management. If a compromise could be reached about the best way to get citizen journalists "up to par" with professional journalists, the possibilities for living in a truly informed society would increase tenfold (Feighery, 2011). According to Lewis (2006), people must look at the nature of "news" in order to enhance the quality of citizenship in our country. 


\section{Current views of user-generated content}

As a whole, not much research has been conducted on the topic of the current perceptions of user-generated content. There seems to be more research considering the audience perspective and what, if anything, they appreciate about user-generated content being incorporated into television news broadcasts that they watch. In a breaking news situation, viewers have something to look at directly from the scene while waiting on a professional television crew to arrive. Usergenerated content adds a "face to the name" type of angle, and it gives viewers a different perspective of news. In a sense, to a viewer, user-generated content can be seen as more authentic, a story from the heart that needed to be told (Wahl-Jorgensen, Williams \& Wardle, 2010).

One possible reason there is little research about news organizations and how management feels about user-generated content is that there isn't one standard procedure for how it should be treated. Every news organization operates differently and, thus, has different opinions about how to best incorporate user-generated content. Although there are concerns about user-generated content, it can be useful.

Importance of news and a well-informed society

Technological advances have made it easier for people to gather news and information, and it is a part of many peoples' daily routines. For example, the Pew Research Center ('In changing news landscape," 2012) found that nearly 15\% of people regularly get their news from a cell phone, tablet, or other mobile device. Viewers don't always have to be at home gathered around the television set to find news because the news is now at their fingertips.

Lewis (2006) outlined three assumptions that reassert the importance of living in an informed, democratic society. First is the importance of informed citizenship, which essentially 
means that society will only be as healthy and well-rounded as the information that people receive. Information is what drives communication and the discussion of solutions to problems. If viewers are not given information that includes all of the facts, society will never make any real progress toward improvement. If people want to be active participants in society then journalists must give them the information they are interested in in order to make decisions.

The second assumption is that the main source of information available to people is broadcast news. This second assumption is supported by a Pew Research Center ("In changing news landscape," 2012) study titled "Watching, reading, and listening to the news." The survey found that $55 \%$ of respondents reported having watched a news program on television daily, compared to $29 \%$ of people who reported reading a newspaper. This finding does not discredit print media; however, it reinforces the shift of broadcast media. Even though broadcast media maintains its position as a top news source, the percentage of people watching has been on a steady decline, according to the latest Pew Research Center State of the News Media report (The State of the News Media, 2013). According to the report, the percentage of young adults under the age of 30 who watch local television news dropped from $42 \%$ in 2006 to $28 \%$ in 2012 . The report also indicated that weather and breaking news are two of the most watched topics on local news. One major factor in the declining percentages of people who are watching under 30 could be that this audience is shifting to online and mobile platforms to get their news.

The final assumption centers around the idea of knowledge. Lewis (2006) argues that regardless of the amount of information, as a whole, the level of knowledge citizens have about certain issues is still relatively low. Beyond that levels of knowledge are not equally divided among social groups, as lower knowledge levels are often seen in families of a lower socioeconomic class. 
Together, these assumptions suggest that moving toward an engaged, active, and informed democracy is still far from reality. This discussion reiterates that citizen journalism could have a helpful place in this world. If user-generated content was better incorporated, news consumers may have access to information they need to be active participants. The citizen journalism initiative could also get citizens who are a part of lower socioeconomic communities more involved and give them an outlet to voice their opinions and be heard, as opposed to not being involved at all (Lewis, 2006).

As reflected in the previous research, the challenge for both traditional and citizen journalists is to figure out a way that encourages relationships between citizens and the media, as well as to integrate the two concepts into a new, successful type of journalism that utilizes citizens and helps satisfy their information needs and wants while still following ethical guidelines.

The technological advancements society has seen over the last several years have played an important part in the way television news has changed. People no longer have to be at home, stationed in front of a television set, to get the news. Now, news is at the world's fingertips at any time. The lack of constraints around news has made it much easier for people to gather and share news with others, including television stations. Although there are some concerns about the implementation of user-generated content in television broadcasts, research has shown that if used correctly, there can be many benefits.

Feighery notes that technology has played a vital role in the implementation of citizen journalism because it allows almost everyone to be on a level playing field (2011). Journalists are forced to adapt to citizens being able to share and fact check information that is published by reporters, creating two-way conversation. Two-way communication, Feighery argues, is what 
engages the public. Miller (2008) echoes these sentiments when he says "as today's tools put the power to publish in the hands of individuals, it is up to traditional media to find ways to incorporate the audience into the news production process" (Miller, pg. 34). One of the benefits Miller discussed is that by involving the audience, a richer product that attracts more attention is produced. A richer, better-rounded product has the ability to draw in more viewers, if there is something on the news they are interested in. Something a viewer had a hand in gathering, producing, or sharing should help maintain a strong relationship between viewers and television news stations, which cover their communities.

Citizen journalism is gaining popularity and is helping to change the news-gathering process. It has created a more open society in which people feel more comfortable to express their opinions and help in the news reporting and dissemination process. Citizen journalism can be viewed in different ways that will help to understand this phenomenon. Two theoretical lenses through which citizen journalism can be viewed are discussed in the paragraphs that follow.

\section{Public sphere}

Citizen journalism is helping to create a more open community where people feel safe to express their opinions, whether it be face to face in a group or on social media (Gillmor, 2004). Television is more immediate than newspapers and, therefore has become one of the fastest ways to transmit news. Thanks to the Internet and social media, citizens from virtually anywhere are able to report news at any time. This creates a place where news is discussed openly and often.

These open communities are called a public sphere, an idea masterminded by Jurgen Habermas (2000). By Habermas' definition, a public sphere is any domain of social life in which public opinions can be shared and even shaped. Under this ideal, the hope is that citizens would come together and act as one entity, one public, when they are dealing with topics that are of 
particular importance to them (Habermas, 2000). One of the major premises of this theory is that it returns citizens to the roots of democracy, where the idea is that every citizen gets a voice in government, a place where their opinions are heard. By getting citizens back to a place where they feel comfortable to share their opinions and ideas, journalism could see significant growth in creating an open environment to discuss news. In a 2012 Pew Research study, only 39\% of respondents believed that news organizations get their facts straight. This finding is a low number considering how much society is driven by media and news consumption. There are a number of factors that determine what sources a journalist uses for a story. The choice of sources could influence viewers' thoughts on the story, and that could help to explain the low number found in the Pew Research study.

The idea of the public sphere is often applied to journalism studies, and, more specifically, it is related to the growth of the Internet and citizen journalism. The Internet is viewed as a "one-stop-shop" of sorts because many news consumers get, share, discuss, and post their news on the Internet. Part of the notion of the public sphere is that it helps to explain where citizen journalism fits on a societal level and what role the development of new technology has played in that shift.

\section{Intermedia agenda setting}

Because of the popularity and presence of the Internet, there has been a revolution in the way news is gathered, told, and shared. The mass media placing emphasis on certain issues over others is referred to as agenda setting, which has been researched extensively by McCombs \& Shaw (1972). Due to this added influence from the mass media, the general public can be influenced on what issues to think about. A more recent idea, intermedia agenda setting, refers to the influence of mass media agendas on each other (Golan, 2006). According to Shoemaker \& 
Reese (1996), news organizations are oftentimes a source for one another. When a story breaks on one television station, it can quickly be picked up by other television stations either locally or across the country (Shoemaker \& Reese, 1996). Influences can exist in every medium, and with new media capabilities like sharing photos, videos, and audio, news can now be gathered, told, and shared within a matter of minutes, which is something television stations are still adjusting to.

There is a process to selecting which news runs and which news does not, and intermedia agenda setting aims to explain how news agendas at different agencies can affect one another. Television is an integral source of information for many citizens (Sweetster, K. D., Golan, G. J., \& Wanta, W., 2006). Not only do television stations influence one another, but now citizen journalists can be grouped into a news media platform of their own. Ibelema and Powell (2001) argued that television has a decisive advantage in terms of having high credibility with viewers. This credibility can be attributed to television's visual realism and the notion that people are more likely to believe what they see (Ibelema \& Powell, 2001). With the added element of usergenerated content, television news stations can gain more credibility. By talking to people who are living and dealing with events and problems in their communities every day, television news stations have the ability to bring citizens into the reporting process.

Citizen journalists have the ability to influence news agendas and, subsequently, public opinion. Citizen journalists' contributions to the news gathering and reporting processes have increased abundantly over the years, and now they are influencing conversations. Having the help of citizen journalists can be especially helpful during breaking news situations. News can be a competitive market, especially when breaking news situations are on the forefront. Several news organizations are rushing to break stories first, and citizens are quickly seeking information 
(Lim, 2011). Citizen journalists have found a niche in this market, as they are able to influence how quickly television news stations cover these stories.

By the contributions alone, citizen journalism is creating two-way communication. By sending in stories that may not be covered by a television station otherwise, citizen journalists are building an agenda they want the public to be aware of. In essence, they are doing their part to influence both the news agenda and the public reality.

The news reality that is being created begs the question of how user-generated content can be most effectively used and how to maintain the relationships between traditional journalists and citizen journalists. With the number of citizen journalism outlets, like the CNN iReport, social media platforms, community blogs, and newsletters circulating throughout any given community, people are likely increasingly less afraid to share their opinions with others.

Researchers like Miller (2008) and Fernando (2008) have agreed that citizen journalism is growing more rapidly than expected, and there aren't many options other than to adapt. If journalism outlets choose to resist the influence of citizen journalism and not adapt to their surroundings, their futures could be in serious jeopardy. As cited in MacIntyre's A short history of Ethics, philosopher Thomas Hobbes writes in his "keys to life" the most important key for survival: "dominate and avoid death" (MacIntyre, 1996). Although he did not originally apply his philosophy to journalism, it makes sense. In terms of journalism, this idea means that in order to avoid the craft's death, one must stay on top of the competition. Researchers all agree that citizen journalism is the "new direction" that society is moving toward, and it is the job of both citizen and traditional journalists to figure out how to forge new relationships (Mayer, 2011). By incorporating user-generated content into their television broadcasts, news stations are 
embracing and sharing news they believe will be of value to their viewers. The current study investigates those tactics to gain a better understanding of how television stations are utilizing user-generated content and how they evaluate and choose to use/not use user-generated content. This research also examines whether stations have adopted either formal or informal policies regarding the use of user-generated content and what these policies entail. 


\section{Chapter 3: Research Questions}

Although there is much research about the growth of citizen journalism and how the Internet has affected it, little research has examined how news from viewers is considered for use at television news stations. To fill this void in the literature, this study seeks to find what, if any, standards and procedures are used by television stations in selecting or rejecting user-generated content for use in television news broadcasts. For the purpose of this research, user-generated content is defined as photos, videos, audio, or ideas to generate stories that are sent to a television news station by an amateur viewer. Thus, the following research questions and are posed:

RQ1: What are the general perceptions of user-generated content?

RQ2: What types of formal, written policies or evaluation procedures are in place, if any, at television news stations to help producers decide if user-generated content will be used during a broadcast?

RQ3: Are there any informal policies at television stations regarding user-generated content?

RQ4: What consistencies, if any, can be found among the policies regarding user-generated content?

RQ5: How often is user-generated content used at television stations across the U.S. (even just to spark a story idea)?

RQ6: What reason was most cited for using user-generated content?

RQ7: What type of user-generated content is most used (photos, videos, audio, or ideas to generate stories that are sent to a television news station by an amateur viewer)?

RQ8: Does market size affect the amount of user-generated content used?

RQ9: How do most stations encourage viewers to submit user-generated content? 


\section{Chapter 4: Method}

The current perceptions of user-generated content, how those perceptions influence editorial policy, and how television stations incorporate user-generated content into their broadcasts were examined through a national web survey of news directors/executive producers at television stations across the country. The following paragraphs detail the data-gathering process, survey implementation, survey instrument, and data analysis.

\section{Data collection}

According to the 2014 Pew Research Center, television is still the most frequently used medium to gather news information (Pew Research Center, 2014). Because there was such a large target sample size, a web survey was selected as the primary method for this study. A web survey is accessible from any computer, and is flexible around monetary and distance constraints for this research. News directors/executive producers at television news stations were selected for this study. News directors/executive producers at these respective television news stations were selected because of their hand in the decision-making process regarding what content makes the news broadcast and what does not.

The sample was drawn using the 2013-14 Nielsen ratings list, which shows there are 210 designated television markets in the United States. In gathering the sampling frame, a census method was chosen in order to reach as many news directors/executive producers as possible. A list of television stations within each market was researched, and the contact information for the news directors/executive producers was collected for each station via the Internet and phone calls to each station, if necessary. 
Using Qualtrics, a web-based survey software program, a panel of participants was built, and the survey was disseminated to 389 participants, which returned nine bounced e-mails. When the survey closed, the data were downloaded into SPSS 19 for review and analysis.

\section{Survey implementation}

Contact with survey participants was executed using a similar approach that is outlined in Dillman's Mail and Internet Surveys: The Tailored Design Method. The initial e-mail invitation to take the survey was sent on March 4, 2014 (See Appendix 1: Initial E-mail Invitation). This initial e-mail invitation was personally addressed to each news director/executive producer to increase the chance of receiving a response. This e-mail included information regarding the research study as well as a respondent-specific link to the consent page and the online survey (See Appendix 2: Survey Instrument; Appendix 3: Consent for Web Survey). Participants were also made aware of alternative ways to take the survey, if they chose, including over the phone and on paper through postal mail. For any emails that were bounced back and determined to be invalid, the station was contacted directly to obtain a valid email address to reduce coverage error.

The next step occurred one week later, on March 10, 2014, when the first reminder e-mail was sent to all potential participants that were included on the first mailing list, unless they specifically e-mailed back and said they were not interested in helping with this study, or if their response had already been received. This first reminder message again was personally addressed, and included a respondent-specific link to the online survey (See Appendix 4: First E-mail Reminder Message). Schaefer and Dillman (1998) found that by including another link to the web survey in the first reminder message, faster returns and higher final response rates were achieved. One and a half weeks later, on March 17, 2014, the second, and final, reminder e-mail 
was sent to non-responders (See Appendix 5: Second/Final E-Mail Reminder Message). Again, this e-mail was personalized and included a respondent-specific link to the online survey. After the initial invitation e-mail and reminder e-mails were sent to participants, 74 people started the survey, while only 44 completed it, for an $11 \%$ response rate.

Due to an incredibly low response rate, additional steps were taken to reach the survey participants. Each individual was called at the television station to ask if they were willing to participate in the survey. For news directors/executive producers who were not immediately available to talk on the phone, voicemail messages were left. For those who indicated they would participate in the survey, the initial e-mail invitation was sent again, with an individual survey link included. After the follow-up phone calls were made, 11 additional responses were recorded, increasing the number of people who started or completed the survey to 85 . However, after downloading and cleaning the data file, it was determined that only 59 responses were usable, as those that did not complete the survey or did not answer a majority of the questions were removed, making the final response rate a disappointing $15 \%$.

News directors/executive producers were given one month (from March 4 until April 3) to complete the survey, to allow ample time for results review and analysis. Approval of this study, survey, and all communication with participants was granted from the Institutional Review Board (IRB) at West Virginia University.

Survey instrument

The 27-question survey (See Appendix 2: Survey Instrument) was designed to be thorough, yet keep time constraints of news directors/executive producers in mind, recognizing time is at a premium in the television industry. After being reviewed by members of academia, the survey was sent to the survey participants. Demographic questions were included to obtain 
basic background information about survey participants. The survey consisted of five-point Likert-type scale items, multiple choice, yes/no, fill-in the blank, five-point semantic differentials and demographic questions. Survey questions were designed and worded to best gauge the perceptions of user-generated content, how often/what type of their work is used in television news broadcasts, and how the shift in journalism is changing editorial policies regarding user-generated content at television news stations across the country. Table 1 displays which survey questions correspond with each research question. 
Research Questions

Survey Questions

RQ1: What are the general perceptions of user-generated content?

$8,9,10,11$

$12,13,14$,

$15,16,17$,

$20,21,22$,

$23,24,25$

RQ2: What types of formal, written policies or evaluation procedures are in place, 3, 3a, 4, 4a if any, at television news stations to help producers decide if user-generated content will be used during a broadcast?

RQ3: Are there any informal policies at television stations regarding user-generated 5, 5a content?

RQ4: What consistencies, if any, can be found among the policies regarding $\quad 4,4 \mathrm{a}, 5$, user-generated content?

RQ5: How often is user-generated content used at television stations across the U.S. (even just to spark a story idea)?

$2,7,18,19,19 \mathrm{a}$ $5 \mathrm{a}$

RQ6: What reason was most cited for using user-generated content?

$8,9,10,11,12,13$ $14,15,16,17,18$, $19,19 \mathrm{a}$

RQ7: What type of user-generated content is most used (photos, videos, 6, 7 audio, or ideas to generate stories that are sent to a television news station by an amateur viewer)?

RQ8: Does market size affect the amount of user-generated content used? 2

RQ9: How do most stations encourage viewers to submit user-generated content? $18,18 \mathrm{a}, 18 \mathrm{~b}$

As previously noted, nearly 400 news directors/executive producers around the country were contacted to participate in this research study. Research conducted at the University of Texas at Austin suggests that for an online survey, a 30-percent response rate is acceptable based on the purpose of the research (University of Texas at Austin, 2011). This research followed the same guidelines, and aimed for a 30-percent response rate from participants. 


\section{Variables}

The purpose of the research was to understand the perceptions of user-generated content, as well as what type of user-generated content is used most often at television news stations. This research also questioned news directors/executive producers about their station's policies—both formal and informal—regarding what dictates whether user-generated content is used/not used in television news broadcasts. For purposes of this research, user-generated content was defined as photos, videos, audio, or ideas used to generate story ideas that are sent to television news stations by an amateur viewer. Formal policies were defined as clearly defined, written-down rules regarding the use or non-use of user-generated content sent to a television news station by an amateur viewer. Informal policies were defined as rules that are not written down, but that are instead implied and understood by all employees at a television news station regarding the use or non-use of user-generated content sent to a television news station by an amateur viewer.

\section{Data analysis}

SPSS 19 was used to review and analyze all data collected from the online survey. Descriptive statistics and frequency analysis were used to analyze each question. A simple linear regression model was used to analyze the research question regarding how well market size predicts use of user-generated content. In order to do the regression analysis, variables were recoded to include the television station market size, known as DMA rank. 


\section{Chapter 5: Results}

The purpose of this research study was to understand what standards and policies are used by television news stations in selecting or rejecting pieces of user-generated content for use in their television news broadcasts, and how that content is integrated into the broadcasts. The general perceptions of user-generated content, and how those perceptions may affect any policies that may be in place were also studied. The frequencies and descriptive means from the corresponding survey questions, outlined in Table 1, were analyzed to assess each research question.

RQ1: What are the general perceptions of user-generated content?

This research question was designed to investigate the overall perceptions of usergenerated content by television news professionals. Six sets of opposite words that could describe user-generated content were chosen, and respondents were asked to indicate their perceptions of user-generated content for each set on a five-point semantic differential scale.

First, for "unprofessional-professional," out of 52 responses, the mean was 2.92. This indicated that most answers were toward the more negative side of the scale. For the second word set, "unhelpful-helpful," the mean of answers was 4.15. This finding indicates a strong sentiment that news professionals believe user-generated content can be extremely helpful. In the context of "bad-good," the mean was a little over halfway, at 3.74. With documented concerns regarding the trustworthiness of user-generated content, the mean for "not trustworthytrustworthy" was similarly close to the middle, falling at 3.24.

Additionally, for "unethical-ethical," the mean was 3.74, which again indicates a positive belief that user-generated content is felt to be more "ethical" than "unethical." Lastly, when 
asked to look at user-generated content in terms of "mal intentioned-good intentioned," the majority of respondents answered closer to "good intentioned," with a mean of 3.9.

These findings suggest that overall, there are positive perceptions of user-generated content. Five out of six answers had a mean over three, indicating a positive feeling. Respondents felt the strongest that user-generated content was more "helpful" than "not helpful," with a mean of 4.15. Second, with a mean of 3.9, respondents indicated they feel user-generated content is "good-intentioned" in nature. In terms of "ethical" or "unethical" and "good" or "bad," each had a mean of 3.74, suggesting more positive feelings. Respondents also suggested that, with a mean of 3.24, they feel that user-generated content is more "trustworthy" than "not trustworthy." The only answer that had a mean of less than three was "professional" or "unprofessional," meaning a majority of respondents feel that user-generated content is more "unprofessional," with a mean of 2.92. From the data collected using these five-point semantic differential scales, respondents indicated there is a mostly positive view of user-generated content, which could contribute to its widespread use at television stations.

RQ2: What types of formal, written policies or evaluation procedures are in place, if any, at television news stations to help producers decide if user-generated content will be used during a broadcast?

The second research question examined whether television stations have formal, written policies in place. Out of 59 responses, $62 \%$ said they do not have a formal, written policy in place, $31 \%$ said they did, and $7 \%$ reported they were unsure of whether a formal, written policy was in place or not (Illustrated in Figure 1). 
Figure 1: Do you have a formal, written policy in place?

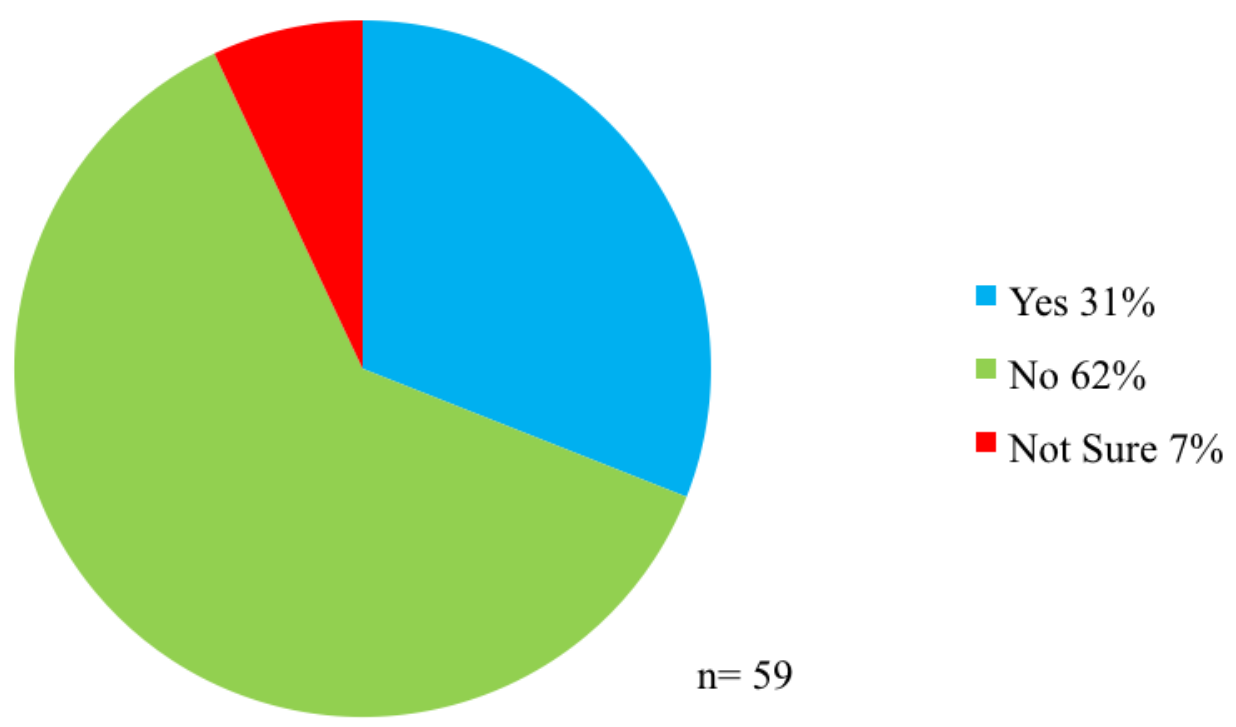

RQ3: Are there any informal policies at television stations regarding user-generated content?

The third research question looked at informal policies regarding the use of user-

generated content. Informal policies were defined as rules that are not written down, but that are instead implied and understood by all employees at a television news station. These responses are shown in Figure 2. 
Figure 2: Does your station have an informal policy in place?

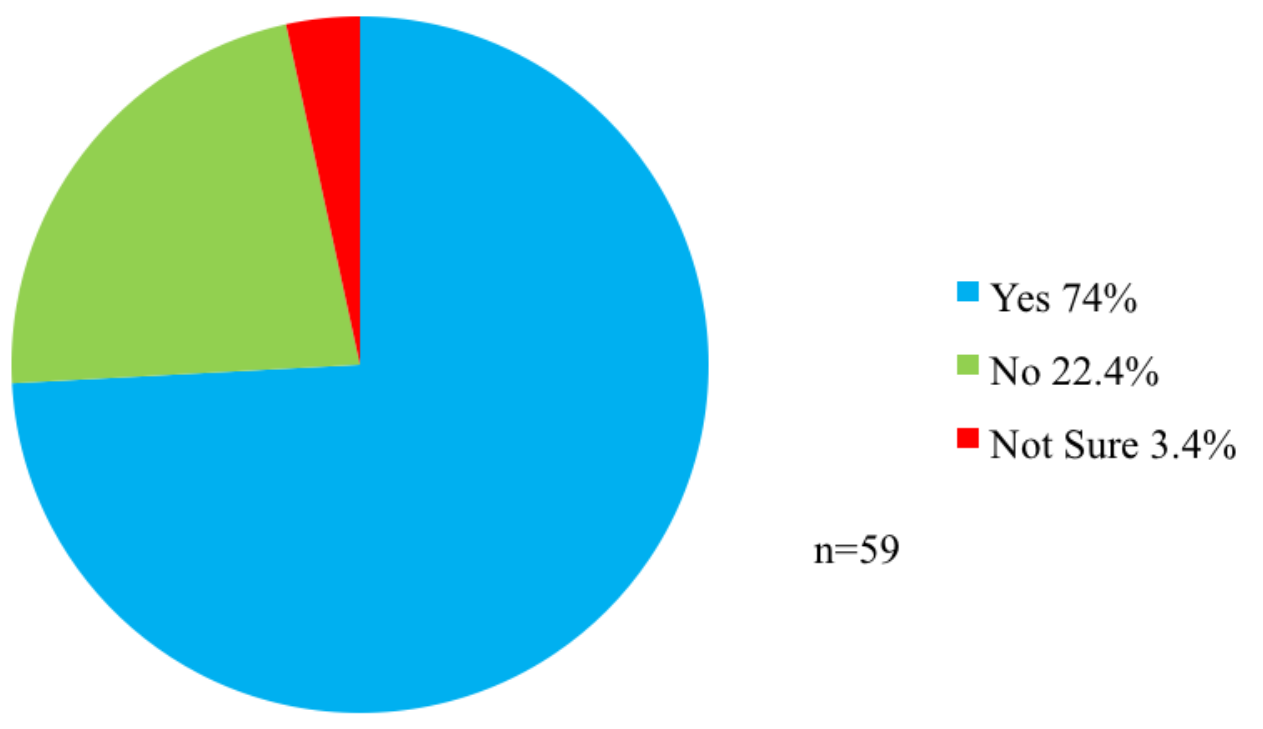

As shown, a majority of respondents indicated that there is some type of understood, informal policy in place at their television news station, which all employees understand and follow in regards to using user-generated content.

RQ4: What consistencies, if any, can be found among the policies regarding user-generated content?

This research question was designed to look at both formal and informal policies, and any similarities that might exist between policies at different stations. Specific details of policies were examined for consistencies and trends that appeared throughout. Open coding was used, to allow themes to naturally emerge, without any expectations of what would be found. Each type of policy and consistencies are discussed in the sections that follow. 
Formal, written policies

Concerning formal, written policies, one of the main trends that emerged was that the content must be vetted by the news director or another professional journalist before it could potentially reach the air on the Internet.

Two other trends also emerged when analyzing these policies. First, a common theme emerged that providers of user-generated content must give up their rights to the content once it is sent to a television news station. Due to copyright concerns, several respondents mentioned that the stations obtain copyright considerations as a precaution.

Second, a majority of respondents expressed that any content that is used, but not produced by the station, is credited to the user if it is used on air or on the station's official website. One respondent mentioned that the source's name must be superimposed over the photo, and stamped with the time and date it was taken before it can be used.

Interestingly, one wrote that "breaking news is a little more lenient in terms of how far in depth we go to vet it, as long as the photo matches the details we already have." This is because television stations would have an easier time vetting content because emergency responders or officials would be on the scene of a breaking news situation. Nonetheless, a majority of respondents indicated that several steps are taken to ensure accuracy and reliability of all content that is not produced by the station. A summary of key consistencies found in formal policies can be found below in Table 2. From the 14 respondents who described their formal policies, a frequency of mention table was created and can be found in Table 3. 
Table 2: Common themes of formal, written policies

\section{Common themes of formal, written policies}

- Content must be vetted by news director/another professional journalist before it can reach the web or the broadcast

- Providers of content must give up their rights to content

- Content must be credited to the creator

Table 3: Frequency of mentions

Frequency of mentions (Formal policies)

\begin{tabular}{|l|c|}
\hline $\begin{array}{l}\text { Reasons } \\
\text { mentioned }\end{array}$ & \% (count) \\
\hline $\begin{array}{l}\text { Content must be } \\
\text { vetted before use }\end{array}$ & $28.5(4)$ \\
\hline $\begin{array}{l}\text { Content creator } \\
\text { must give up } \\
\text { rights to content } \\
\text { after submission }\end{array}$ \\
\hline $\begin{array}{l}\text { Content must be } \\
\text { credited/sourced } \\
\text { before use }\end{array}$ \\
\hline
\end{tabular}




\section{Informal policies}

Respondents were also asked to describe any informal policies that are present at their television news stations. A number of consistencies were again found among the answers. First, several respondents noted that all content must be evaluated before it can be used. Most content must be cleared by a news director, assistant news director, managing editor, or another equally authoritative person if it could be seen as controversial in nature. As one respondent noted, "It depends on the story - a weather event is treated a lot different than a shooting. If a producer is in doubt whether to use the picture or not then error on the side of caution of not using it. We are always discussing this topic."

Second, a majority of respondents noted that all content is checked for sources and said it should not be used until the source can be properly identified, and the content is checked for relevance and accuracy. Many noted that their informal policies are much in line with "common sense" and that if there are any questions or concerns, the content will not be used, and it must be void of any profanity, vulgarity, and cannot be offensive in any way.

All told, whether the policy was formal or informal, much of the same premises were found. Television stations take extreme caution when determining whether or not to use pieces of user-generated content. No matter the difference in how the policies are made, sourcing, vetting, and checking content for relevance and accuracy remained important aspects throughout. Table 4 displays a summary of common themes found in informal policies. Respondents were asked to describe their informal policies, which 34 respondents did. Table 5 displays the key consistencies found in informal policies and outlines the frequency of mentions from the 34 respondents who described their informal policies. 
Table 4: Common themes of informal policies

\section{Common themes of informal policies}

- All content must be evaluated before use

- All content must be sourced, said content should not be used until the source can be properly identified

- Generally, if there is a question or concern, content will not be used

Table 5: Frequency of mentions

\begin{tabular}{|l|c|}
\hline \multicolumn{2}{|l|}{ Frequency of mentions (Informal policies) } \\
\hline $\begin{array}{l}\text { Reasons } \\
\text { mentioned }\end{array}$ & \% (count) \\
\hline $\begin{array}{l}\text { Content must be } \\
\text { evaluated before } \\
\text { use }\end{array}$ & $35.2(12)$ \\
\hline $\begin{array}{l}\text { Content must be } \\
\text { sourced before use }\end{array}$ & $35.2(12)$ \\
\hline $\begin{array}{l}\text { If there is a } \\
\text { concern regarding } \\
\text { its use, it will not } \\
\text { be used }\end{array}$ & 11.7 (4) \\
\hline
\end{tabular}


RQ5: How often is user-generated content used at television stations across the U.S. (even just to spark a story idea)?

The purpose of this research question was to examine the three most common times news broadcasts are run throughout the day and to use those to help determine when user-generated content is most often used. Respondents were asked to fill out approximately how many pieces of user-generated content are run in their morning, afternoon, and evening newscasts for both weekdays and weekends. From those numbers, the means and standard deviations were calculated to answer this question. Significance tests were not run due to the small sample size. The standard deviations indicate a large amount of variance, showing the data were spread out over a large range.

Shown in Table 6, the most pieces of user-generated content are typically shown during a morning or evening broadcast during the week, with averages of 3.28 and 2.42 per newscast, respectively. The averages were found to be markedly lower for all weekend broadcasts. The lowest was found to be a weekend broadcast running during the afternoon hours, at 49 . 
Table 6: How often is user-generated content used?

\begin{tabular}{|c|c|c|c|}
\hline Weekdays & Weekends & & $\begin{array}{l}\text { Total means } \\
\text { and standard } \\
\text { deviations }\end{array}$ \\
\hline $\begin{array}{l}\text { Mean }=3.28 \\
\mathbf{S D}=4.064\end{array}$ & $\begin{array}{l}\text { Mean }=1.35 \\
\mathbf{S D}=3.236\end{array}$ & Morning & $\begin{array}{l}\text { Mean }=4.79 \\
\mathbf{S D}=7.14\end{array}$ \\
\hline $\begin{array}{l}\text { Mean }=1.57 \\
\mathbf{S D}=3.188\end{array}$ & $\begin{array}{l}\text { Mean }=.49 \\
\mathbf{S D}=1.295\end{array}$ & Afternoon & $\begin{array}{l}\text { Mean }=1.82 \\
\mathbf{S D}=3.29\end{array}$ \\
\hline $\begin{array}{l}\text { Mean }=2.42 \\
\mathbf{S D}=2.140\end{array}$ & $\begin{array}{l}\text { Mean }=2.00 \\
\mathbf{S D}=2.096\end{array}$ & Evening & $\begin{array}{l}\text { Mean }=4.57 \\
\mathbf{S D}=4.21\end{array}$ \\
\hline $\begin{array}{l}\text { Mean }=7.54 \\
\mathbf{S D}=9.26\end{array}$ & $\begin{array}{l}\text { Mean }=3.26 \\
\mathbf{S D}=3.66\end{array}$ & & $\begin{array}{l}\text { Total means } \\
\text { and standard } \\
\text { deviations }\end{array}$ \\
\hline
\end{tabular}

Overall, for this research question, afternoon news broadcasts seemed to be the weakest in terms of pieces of user-generated content used, and a weekday morning came out as the strongest. These findings indicate that typically (barring a breaking news situation), weekend broadcasts do not contain nearly as much user-generated content as do weekday broadcasts.

RQ6: What reason was most cited for using user-generated content?

The purpose of this research question was to understand why stations use user-generated content during their television broadcasts. To measure this research question, a series of 10 questions were designed, each using a five-point Likert scale. Survey respondents were asked to select their level of agreement, ranging from strongly disagree to strongly agree, with each statement regarding the use of user-generated content. A frequency analysis was run to determine how strongly respondents felt about each scenario and the role it plays in using user-generated 
content. The means and standard deviations were also calculated. All findings are shown in Table 7. 
Table 7: Reasons cited for using user-generated content

\begin{tabular}{|l|l|l|l|l|l|l|}
\hline $\begin{array}{l}\text { Reasons for } \\
\text { using user- } \\
\text { generated } \\
\text { content }\end{array}$ & $\begin{array}{l}\text { Strongly } \\
\text { disagree }\end{array}$ & Disagree & $\begin{array}{l}\text { Neither } \\
\text { agree nor } \\
\text { disagree }\end{array}$ & Agree & $\begin{array}{l}\text { Strongly } \\
\text { agree }\end{array}$ & Mean (SD) \\
\cline { 2 - 7 } & $\%$ (count) & $\%$ (count) & $\%$ (count) & $\%$ (count) & $\%$ (count) & $\%$ (count) \\
\hline Time constraints & $5.4(3)$ & $23.2(13)$ & $8.9(5)$ & $41.1(23)$ & $21.4(12)$ & $3.50(1.221)$ \\
\hline $\begin{array}{l}\text { Budget } \\
\text { constraints }\end{array}$ & $14(8)$ & $36.8(21)$ & $21.1(12)$ & $19.3(11)$ & $8.8(5)$ & $2.72(1.192)$ \\
\hline $\begin{array}{l}\text { Staff constraints } \\
\text { Personal } \\
\text { perspective }\end{array}$ & $7.1(4)$ & $16.1(9)$ & $14.3(8)$ & $46.4(26)$ & $16.1(9)$ & $3.48(1.160)$ \\
\hline $\begin{array}{l}\text { Eye to breaking } \\
\text { news }\end{array}$ & $1.8(1)$ & $3.6(2)$ & $5.4(3)$ & $46.4(26)$ & $42.9(24)$ & $\mathbf{4 . 2 5}(.858)$ \\
\hline $\begin{array}{l}\text { Better } \\
\text { relationship } \\
\text { with viewers }\end{array}$ & $0(0)$ & $1.8(1)$ & $26.8(15)$ & $50(28)$ & $21.4(12)$ & $\mathbf{3 . 9 1}(.745)$ \\
\hline $\begin{array}{l}\text { Quality of } \\
\text { broadcast }\end{array}$ & $0(0)$ & $5.4(3)$ & $21.4(12)$ & $50(28)$ & $23.2(13)$ & $\mathbf{3 . 9 1}(\mathbf{. 8 1 5})$ \\
\hline $\begin{array}{l}\text { More } \\
\text { economical }\end{array}$ & $32.1(18)$ & $46.4(26)$ & $12.5(7)$ & $7.1(4)$ & $1.8(1)$ & $2.00(.953)$ \\
\hline $\begin{array}{l}\text { Focus on bigger } \\
\text { stories }\end{array}$ & $10.7(6)$ & $51.8(29)$ & $25(14)$ & $12.5(7)$ & $0(0)$ & $2.39(.846)$ \\
\hline $\begin{array}{l}\text { Better connect } \\
\text { with viewers }\end{array}$ & $0(0)$ & $1.8(1)$ & $19.6(11)$ & $50(28)$ & $28.6(16)$ & $\mathbf{4 . 0 5 ( . 7 4 9 )}$ \\
\hline
\end{tabular}

$\mathrm{n}=59$ 
Of the options provided, the strongest response came from the idea that user-generated content allows viewers to get an "eye" into a breaking news situation until a professional crew can get to the scene. Nearly half, $46.4 \%$, of respondents indicated they "agreed," while $42.9 \%$ of respondents said they "strongly agreed," for an $89.3 \%$ total. The mean was calculated to be 4.25 . With such a strong positive feeling, the overwhelming majority of survey respondents agreed that this was a major reason for using user-generated content.

Along with that connection, the survey respondents also strongly agreed that using usergenerated content in television broadcasts allows them to better connect with their viewers. Half "agreed" with that sentiment, while nearly $30 \%$ "strongly agreed" that user-generated content allows them to better connect with their viewers. This research question recorded a 4.05 mean, indicating this is another strong reason for television stations using user-generated content.

In terms of user-generated content helping to build a good (or better) relationship with the communities they represent, television news professionals strongly indicated they believe it does. Over $70 \%$ of respondents noted that they believe that statement.

Another strong response was received to the "user-generated content helps to enhance the quality of the broadcast" question. Over $70 \%$ of news directors "agreed" or "strongly agreed" that they feel their news broadcasts are better when using user-generated content.

Participants also responded strongly to the idea that user-generated content can provide a more personal perspective to news, with over $76.8 \%$ either "agreeing" or "strongly agreeing." News viewers can get a more personal perspective from the news when content is provided by the people who live in the local and surrounding communities. 
Additionally, closer to half of the survey respondents indicated that time and staff constraints are sometimes reasons they use user-generated content. When asked if time constraints were a determining factor in using user-generated content, just over $62 \%$ either "agreed" or "strongly agreed" with that statement. Likewise, approximately $62 \%$ also either "agreed" or "strongly agreed" with the statement "user-generated content helps to tell stories that the station can't necessarily cover because of staff constraints."

However, not all of the questions were met with a positive response. When asked about the statement "Our television news station uses user-generated content because of budget constraints," a majority of respondents answered on the negative side of the Likert scale. With a mean of only 2.72, news directors did not strongly agree with budget constraints as a reason for using user-generated content.

Finally, using user-generated content so that the professional staff can focus on bigger, more important stories, and using user-generated content because it is more economical were the statements that news directors disagreed with the most. When asked about using user-generated content so that professional staff can focus on bigger, more important stories, the mean was 2.39. When considering the idea that user-generated content is more economical than paying more reporters, the mean was markedly lower, at 2.00, indicating a strong disagreement with the statement.

The results indicated that the most popular reasons for using user-generated content stemmed from forming better relationships with viewers, and the communities that the television stations represent. By giving viewers an "eye" into breaking news situations, the stronger 
relationships are formed because viewers are able to take an active role in the news gathering process. In turn, the local perspective helps to enhance the quality of the television broadcast.

From the responses that showed a level of disagreement, two out of three were related to monetary constraints. By showing strong levels of disagreement to the statements, news directors indicated that monetary constraints are not a reason to use user-generated content. News directors also made it a point to indicate that they do not rely on user-generated content as a primary news gathering source, because they disagreed with the statement "using user-generated content allows our professional reporters to focus on bigger, more important stories."

Overall, this research question indicated that news directors believe in using usergenerated content as supplemental material to what their stations have the resources to produce. They also strongly agreed that some of the main reasons for using user-generated content is because it helps to involve the communities in which their news stations represent. News directors indicated they believe much more strongly in enhancing their relationships with the community, and not "cutting corners" by down-playing their content for bigger, more important stories.

RQ7: What type of user-generated content is most used (e.g., photos, videos, audio, or ideas to generate stories that are sent to a television news station by an amateur viewer)?

The purpose of this research was to examine how user-generated content is used in television news broadcasts; therefore this specific question was posed to find out what type of content is used most. Respondents were only able to select one response to this question. By a strong margin, the majority of respondents indicated that on a regular basis, photos are used most often in television news broadcasts (Illustrated in Figure 3). Following photos, nearly 16\% of 
respondents indicated it was story ideas which were used most in television news broadcasts. Nearly two percent of respondents indicated that videos are used most, while none reported audio as being used most in broadcasts.

\section{Figure 3: What type of user-generated content is used most?}

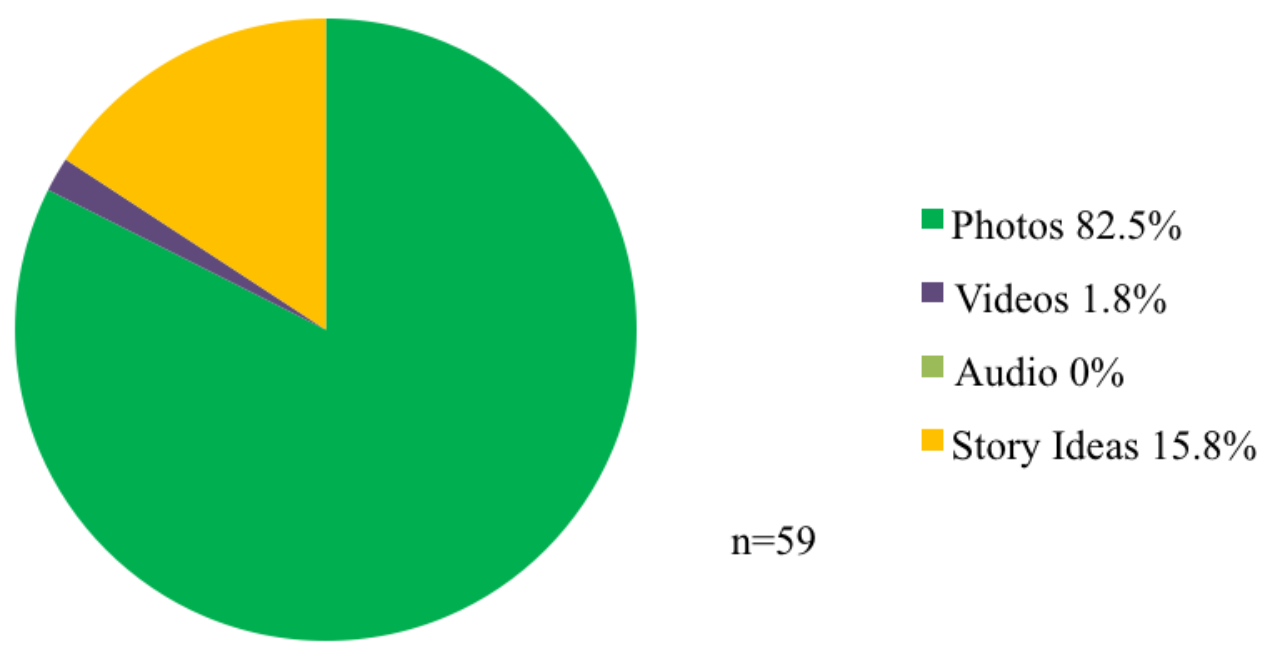

RQ8: Does market size affect the amount of user-generated content used?

For this research question, a simple linear regression analysis was used to test if market size predicts use of user-generated content. The results of the regression indicated that there is an inverse, but clearly non-significant, relationship between television market size and the use of user-generated content. Simply, market size was a non-factor in predicting the use of usergenerated content. The regression analysis revealed an inverse, non-significant relationship, where $\mathrm{r}^{2}=.007, F(1,30)=.213, \mathrm{p}=.648 ; \beta=-.085, \mathrm{p}=.648$. Therefore, there was no significant relationship between market size and the use of user-generated content.

RQ9: How do most stations encourage viewers to submit user-generated content?

Answers to previous research questions noted several concerns that television news professionals have regarding the use of user-generated content. When asked if they encourage 
viewers to send in pieces of user-generated content, an overwhelming majority, $89.5 \%$, reported that they do (Illustrated in Figure 4).

\section{Figure 4: Does your station encourage viewers to send in pieces of user-generated content?}

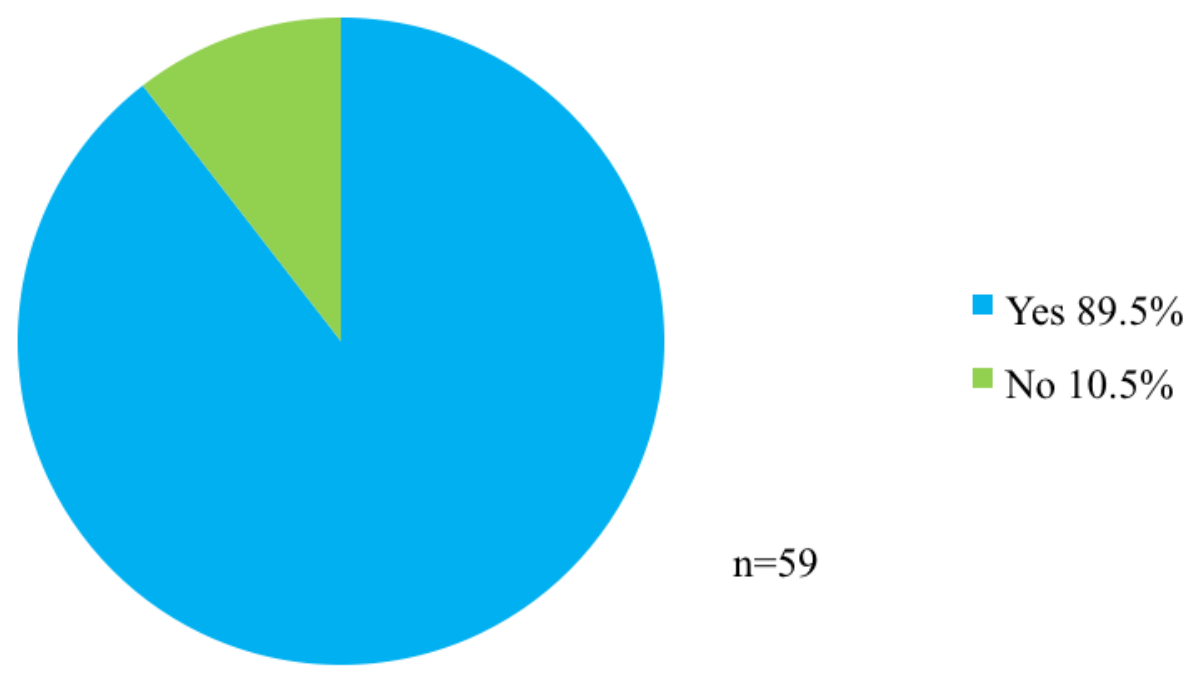

If respondents indicated they do encourage viewers to submit user-generated content, they were asked how they encouraged viewers to do so. This question was multiple choice, and respondents could select as many applicable answers as necessary. The most-selected answer was encouragement during the live broadcast, as $47.5 \%$ of respondents indicated this was the primary way they encouraged the public to send in pieces of user-generated content. Of that $47.5 \%$, nearly all respondents indicated that during the live broadcast, there was a commercial spot that was run, or the on-air personalities personally appealed to the public for content.

Second most, unsurprisingly so, was through the use of social media. Most often, television news personalities have Facebook and/or Twitter accounts, and $27.1 \%$ of respondents indicated this was the most popular way they reach out to their viewers for user-generated content. A complete list of responses is illustrated below in Table 8 . 
Table 8: How stations encourage viewers to send in pieces of user-generated content?

\begin{tabular}{|l|c|}
\hline $\begin{array}{l}\text { How do stations encourage viewers to send in } \\
\text { pieces of user-generated content? }\end{array}$ & Percent (count) \\
\hline $\begin{array}{l}\text { We have a designated place on our website where we } \\
\text { encourage viewers to send us information regarding a } \\
\text { story or event, or to send us photos, videos, or audio. }\end{array}$ & $42.4 \%(25)$ \\
\hline $\begin{array}{l}\text { We regularly require our reporters to use their work } \\
\text { Twitter and Facebook accounts to encourage viewers to } \\
\text { send in user-generated content. }\end{array}$ & $27.1 \%(16)$ \\
\hline $\begin{array}{l}\text { We encourage our reporters to ask for information and } \\
\text { pieces of user-generated content while they are } \\
\text { reporting in the field. }\end{array}$ & $22 \%(13)$ \\
\hline $\begin{array}{l}\text { We encourage our viewers to send in pieces of user- } \\
\text { generated content during our news broadcasts. }\end{array}$ & $47.5 \%(28)$ \\
\hline \multicolumn{1}{|c|}{$=59$} & \\
\hline
\end{tabular}

If respondents answered no, to indicate that they do not encourage viewers to send in pieces of user-generated content, they were asked to expand upon that answer and explain why they do not. The answers varied somewhat, but the majority of the respondents explained that the news stations allow the viewers to take initiative on sending in content. As one respondent noted, “We don't heavily promote it, but we don't discourage it either. Simply put, we don't promote heavily any viewer sending in tips." Another noted, "We don't encourage our viewers to send in user-generated content, but if we receive any, we may or may not use it." 


\section{Summary of findings}

The survey responses provided ample amounts of valuable information in regards to this research. The results showed that informal policies are more prevalent than formal, written policies at television news stations, but that user-generated content is strong in terms of use across the country. While only $31 \%$ of respondents indicated their station has a formal, written policy, participants relayed that extreme caution is always taken when deciding to use or not use pieces of user-generated content. Nearly all respondents made some mention of vetting and sourcing any type of user-generated content before it has the chance to be used. One respondent noted that user-generated content is in "no way" going to replace the need for journalists. While user-generated content can help to put a story into perspective, it cannot replace professional quality work from broadcast professionals.

The other prominent theme that appeared was that user-generated content is more often than not used as just supplemental material to that which the news station gathers, as opposed to the primary news gathering source. As one respondent noted, "We will not use something submitted unless it contains a visual element we failed to capture." At the end of the survey, respondents were asked if they had any additional information they wanted to add regarding user-generated content at their station. One of the most interesting responses read "If local television news doesn't begin to listen to our viewers and respond to them, we will become extinct as dinosaurs."

From the responses gathered, it appeared that nearly everyone who responded understands the benefits of user-generated content. However, just because there are benefits to using user-generated content doesn't mean the best way to do it has been figured out. Every 
television broadcast station has different rules and tendencies, but the research showed they're each taking a slightly different approach in how to go about incorporating it. A summary of key findings can be found below in Table 9.

Table 9: Summary of key findings

\begin{tabular}{|l|}
\hline Key findings \\
\hline - \\
$\begin{array}{l}\text { Informal policies are more prevalent than } \\
\text { formal, written policies }\end{array}$ \\
- $\begin{array}{l}\text { Nearly all respondents mentioned } \\
\text { vetting/sourcing all user-generated } \\
\text { content }\end{array}$ \\
- $\begin{array}{l}\text { User-generated content is primarily used } \\
\text { as supplemental material, not as the } \\
\text { primary news gathering source }\end{array}$ \\
\hline
\end{tabular}




\section{Chapter 6: Discussion}

The purpose of this research was to understand perceptions of user-generated content, investigate policies at television news stations across the country, and to determine how those policies affect the use of user-generated content. For the purposes of this research, usergenerated content was defined as photos, videos, audio, or ideas to generate stories that are sent to television news stations by an amateur viewer. Frequencies and descriptive statistics were used to analyze the results of this research, which yielded interesting findings regarding the use of user-generated content.

Survey respondents indicated a mostly favorable view of user-generated content, which increases the likelihood it will continue to be used, despite the documented reservations surrounding its use. The majority of survey respondents indicated that they found user-generated content to be more helpful, ethical, good, and good-intentioned than the negative counterparts. This mostly favorable outlook about user-generated content suggests that many television stations use it regularly, and this falls in line with their desire to better the relationships with viewers in their community. This study found that there are more positive than negative perceptions of user-generated content, and numerous benefits from using it, like enhancing the quality of television news broadcasts, and giving a local, inside perspective to news that was previously unattainable due to a lack of accessible technology to the average viewer.

Although there were a larger number of informal policies than there were formal policies, many of the pillars remained the same. Nearly every respondent noted some of the same general ideas and concerns regarding user-generated content and its use during television news broadcasts. Many respondents shared concerns similar to those found in the literature review, which include a variety of issues. Some of those concerns were legal in nature, while others were 
concerned with the quality, relevancy, and accuracy of any user-generated content provided to television news stations. Because citizen journalists are not trained, Brown (2005) noted that citizens don't have any credibility with regards to the content they provide, which could still play an important role in determining how individual news outlets decide to use or not use pieces of user-generated content.

This study's findings suggest that the use of user-generated content is fairly consistent throughout the United States, as it is used regularly in nearly all television news broadcasts. Unsurprisingly, respondents indicated that user-generated content is most often used during a morning or evening broadcast during the week. This increase could be due to time of day, because more cars are on the road, which increases chances for motor vehicle accidents. Breaking news makes up a large amount of user-generated content, and more viewers would be out during typical commuter travel hours, increasing the chance they could come across a newsworthy breaking news situation. The increased amount of use could also be due to the formatting of the content itself. If a piece of content is received in the morning, it may take a few hours, or all day, to properly vet the content and format it for the proper technical aspects the television news broadcast requires. After that is done, the user-generated content may not be ready for use until the evening news broadcast.

No matter when the content is used, there were strong indications of why television news stations decided to use user-generated content. The most selected responses for using usergenerated content fell under the blanket idea of quality. Whether it was increasing the quality of the broadcast itself, or using the content as a way to enhance the quality of relationships with viewers in the community, several news directors indicated those as the main reasons for using user-generated content. Having gone through so many shifts and changes in terms of how people 
receive news, these reasons fall in line with television news stations trying to adapt to the everchanging technology, as to not lose viewers to other media like the Internet and mobile applications.

The findings suggest that television news broadcasts incorporating user-generated content into their broadcasts is a win-win situation, for both the television station and the viewers. By providing a better quality broadcast, with more local perspectives and first-hand accounts of both breaking and local news, television stations are able to work better within their communities, and maintain strong viewership despite rapid technological advances.

There are many different types of user-generated content, but this research was focused on photos, videos, audio, and ideas to generate stories as the primary types. Nearly all respondents, by a vast majority, indicated that photos are used most often during television news broadcasts. This could be due to several factors, but the most prominent would be accessibility and ease of delivery. Most television stations now have some type of way to submit content, either online, through e-mail, through text or mobile application. Photos are easy to take, especially now with smartphones that are equipped with high-quality cameras. Photos can be sent and received within a matter of minutes, which becomes extremely helpful in times of breaking news, because there can be a constant flow of information sent to a news station for continuous updates. Smartphones make it easier than ever to pull up the camera and start snapping away. Because of the high-quality, these photos would be easy to format for use in a television news broadcast, and even to obtain a time and date stamp from, as most phones now include those details in the photo information. 
Despite its widespread use, this research indicated that the market size of the station does not predict the use of user-generated content. It would be understandable to think that smaller stations use more user-generated content, because they may not have as many resources to cover all of their stories. However, it could also be understandable to consider the reason smaller stations don't use more user-generated content is because they may not have the capabilities to format it, and the town residents may not have the technological capabilities to submit any content. No significant relationship was found between these two variables, suggesting that there is no relationship between the market size and use of user-generated content. The lack of a significant relationship upholds the notion that the use of user-generated content is widespread across the United States.

The popularity of user-generated content could mean that television news stations are encouraging viewers to send in content as a way to engage the community. A strong majority, $89.5 \%$, of respondents indicated that their station does encourage viewers to send in pieces of user-generated content. Of those respondents, nearly half said this encouragement is mainly done during the live broadcast. There is a strong likelihood that this method of encouragement is done live because it is a passive experience for people to watch the news, and the viewers don't have to get online or call the station to figure out how to submit content.

Overall, there has been little research has been done regarding user-generated content and its integration into television news broadcasts. Outside of knowing that the use of user-generated content is on the rise, there isn't much literature. The main contributions of this research are that we now have a much clearer understanding of why television stations use user-generated content, and we also have a much better idea of how those perceptions shape policies dictating its use. Because of the concerns that survey respondents dictated in their survey answers, they also 
explained that their policies reflect the technological access and knowledge viewers have, and how to protect against potentially altered content, as to maintain the reputation of the stations. Thinking about the access that viewers now have, it isn't surprising that concerns shape policies quite a bit. The chance of receiving altered content is higher now than it likely was ever before, which likely leads broadcast news professionals to make some type of policy to guard against that possibility.

Despite the extremely low response rate, the information gathered falls in line with Habermas' notion of the public sphere, and the idea of intermedia agenda setting, in that by submitting user-generated content, community members feel more comfortable in shaping and influencing public opinion. Technology increases influence over what, and how, news is reported, which is a significant step in a more involved public.

One of the major premises of this theory is that by returning citizens to the roots of democracy, where every citizen has a voice that is heard. Respondents suggested that hearing the voices of the citizens they represent is an important factor in why they use user-generated content. In a way, user-generated content helps to nurture relationships with community members, which is what Habermas wanted. The research indicated that television news stations are making a concerted effort to work with community members and grow relationships with them, even if they don't always use user-generated content.

The notion of community is what drives Habermas' theory, and it is significantly aided by user-generated content, because it is a way for the community to feel involved and to see their input first-hand. Newsrooms are a professional environment, but are making strides toward also becoming a place where community members feel comfortable to take their ideas, frustrations, 
and content. A more involved, active community was one reason cited by survey respondents for using user-generated content. There was a positive response reported to the statements "using user-generated content allows us to better connect with our viewers," and "it helps us form a good (or better) relationship with the community," indicating that involving the community is one of the main reasons for using user-generated content. The results showed that television news stations are striving to find a balance between how to protect the broadcast television craft, while using new and innovative content and ideas to do that.

It is well documented that times are changing, and even television is losing ground to mobile applications and capabilities. This research shows that television stations are well aware of this and are moving toward more integration of user-generated content, while still working diligently to maintain their basic, yet critical, journalistic principles. Warren Breed's Social Control in the Newsroom: A Functional Analysis, discusses how newspaper publishers and chief executive officers get their journalists to follow policies, even though those policies aren't often written down. Though this study specifically covers print media, lessons can be taken away that cover all forms of journalism.

Breed discovered that many journalists learn policies through osmosis, essentially learning through observation in the newsroom. Breed's research showed there are many factors at play when journalists decide to follow policies, including reprimand by superiors and not having stories printed or run on air if a mistake is made. Especially in regard to informal policies, they can, and usually do, differ on a case by case basis, meaning they are not always clear cut in providing an answer. 
Breed's work also discusses how media consumers have power over the performance of their media outlets, whether it be their local newspapers or television stations. Breed concluded that if consumers are not happy with the content they are receiving from their media outlets, they very much have the ability to take on a larger role and change, or enhance, the performance of those outlets (Breed, 1955).

Overall, Breed's findings suggest that despite the ever-changing culture of news, and the newsroom, policies have a wide scope and cannot cover every situation. Changes in policies are largely influenced by how media consumers react to the product they are given, and with the changes and advancements in technology, those expectations are continuing to rise.

Having any type of policy at a television station should help to quell concerns of usergenerated content, but of course it does not stop all problems. The results of this research showed that the collaborative relationship between television news stations and viewers is still somewhat distant because user-generated content is used primarily as supplemental material. It is not the primary news-gathering method, as many respondents suggested, but what this research did show is that television news stations do recognize they need to work with the community in order to survive the technological boom.

\section{Method Limitations}

As with any study, this research had a few limitations. First, the very low response rate of the survey was a difficult obstacle to overcome. Being the ultimate decision-makers for whether to use user-generated content, the potential participants were hard to get in contact with, hindering the low response rate. After follow-up calls were made to non-responders, and the data was cleaned, it was determined that only 59 responses were usable, bringing the response rate to 
a disappointing $15 \%$. The low response rate can be tied to the workload of the potential participants, as well as the time of year in which the survey was conducted. Sweeps were conducted through the month of February, so news directors could have been occupied with completing sweeps requirements for their respective stations during the time of the survey.

Additionally, in-depth interviews were not conducted because of time constraints of the participants. The policies that were collected and/or described by the survey respondents provided the necessary information for the completion of the research. By asking for a description (or link to) the policy, the information provided was strong enough to stand alone without the supplemental information that would have been given during a follow-up interview.

Social desirability bias could have been a factor in some of the answers received. Respondents may have felt that they should respond with an answer that wasn't completely truthful because they thought it was what researchers wanted to hear. Social desirability bias could be a factor any time questions of perceptions are asked.

For future research, the same study could be completed, but with a much larger response rate to get more generalizable results. Also, the study could be completed with news reporters. Although news reporters do not make the final decision on what does or does not make the final newscast, their input would be a helpful supplement to further understand the growing use of user-generated content.

Additional future research should also include a content analysis of breaking news coverage, to see how much of it is comprised of pieces of user-generated content. The research indicated that breaking news coverage typically includes more user-generated content, so it would be interesting to see exactly how much user-generated content is used during those times. Another interesting observation to make in future research would be to look for if, or how, user- 
generated content could become more legitimized as a news source. Respondents to this study pointed out they feel this type of content tends to be more "unprofessional," yet we often see it used, especially when a news station has missed getting the visuals and it can be used to their benefit. How this type of content could become more "professional" and gain legitimacy would be an interesting development to watch.

\section{Strengths}

Working with a web-based survey did, however, offer many benefits. First was the immediacy of the response. Responses were able to be tracked every day. For the benefit of the participants, an online survey provided more privacy because they were able to take it from any location. Unlike a phone survey, respondents were able to take the survey from any computer, and were not required to do it on a work computer. Due to the variance in location of the respondents for this survey, doing a mail survey would have been extremely costly and nearly impossible to track. Respondents came from stations all across the United States, so it was much more time efficient to let them have the survey to complete at their convenience.

Perhaps the most important benefit of this research is that it got news directors and broadcast professionals thinking and talking about the idea of user-generated content and how it can be used in television news broadcasts. Seen by the amount of informal policies, it could be that many television news stations didn't see a need to have a written, formal policy. However, by conducting this research, news directors now understand the rate at which the use of usergenerated content is increasing, and how having policies in place regarding its use can be helpful, and even necessary. 


\section{Chapter 7: Conclusions}

Overall, this research is important because it opened a window into the phenomenon of user-generated content, and how it is being incorporated into television news broadcasts.

Television is one of the most popular news-gathering mediums, and there was a surprising lack of research done on the integration of user-generated content into news broadcasts. The existing research on user-generated content only explained that it was becoming more popular, most in part due to social media and technology being more accessible now than ever before. This research study was specifically chosen because it incorporated two of the most popular newsgathering mediums and looked at how they interact with one another, and in turn, how that interaction influences policies.

This research study suggests that even with legitimate concerns, user-generated content is still — for the most part—looked at as a secondary tool for the work that professional broadcast journalists do every day. Although user-generated content is not viewed as the primary news gathering source, it certainly has proven itself as helpful. This is especially true in cases of breaking news when, generally speaking, there are people around who can capture the action and provide news teams with updates and content as they are on their way to the scene. Survey respondents made sure to note that user-generated content, if vetted and sourced properly, can be used as supplemental content that professional news crews may not have been able to capture.

This dynamic relationship should certainly be explored further, as this research study provided just a snapshot example of the opinions and policies that are prevalent at television news stations. It would be interesting to expand this research study with a larger response rate to see if a significant relationship existed between television station market sizes and the use of user-generated content. This variable was looked at in the current research study, but only an 
inverse, non-significant relationship was found, likely due to the incredibly low response rate. For example, it would be understandable to think that perhaps smaller markets use more usergenerated content because they don't have as many resources. It would also make sense to think that smaller markets may use less user-generated content, because there may be a technological gap, especially if the station is located in a rural, smaller town with less resources altogether. Because of the low response rate for the current study, these ideas were not able to be researched further. However, future research into this topic would make a significant advancement if market size and use of user-generated content could be studied.

This research can absolutely help strengthen knowledge surrounding user-generated content and, by knowing what policies exist and what the concerns are, help to generate more communication between television news stations and the viewers they represent. Strengthening the sense of community, and giving viewers a more personal perspective of news, all while still maintaining a credible reputation is becoming easier. However, this is only being made easier by policies that are in place to guard, but not shut out, pieces of user-generated content. 


\section{Appendix 1: Initial E-mail Invitation}

Dear $<<$ Salutation $>><<$ Last_Name $>>$,

I am writing to ask for your help in an important research study regarding the use of usergenerated content in television broadcasts. This study is being conducted as part of my master's thesis research at the Perley Isaac Reed School of Journalism at West Virginia University. Dr. Rita Colistra is the committee chairperson for this research. West Virginia University's Institutional Review Board (IRB) has acknowledgement of this study on file.

This research study is important because it will help us to better understand the practices and/or policies at television stations regarding the use of user-generated content submitted by an amateur viewer, as well as to gauge general perceptions of this type of content. Your response is critical to the study's success because you are a key decision maker regarding content on news broadcasts. The research study can be found at this address: <<survey_URL〉>.

Your answers will be kept private and confidential. I guarantee that your responses will not be connected to you personally. The results of this project will be analyzed in various formats, but your answers will not be matched with you. Participation in this survey is voluntary, and you may choose to opt out at any time. However, I do hope that you will choose to participate, as your input will add value to this project. To participate, the survey can be found at this address: <<survey_URL>>.

If you choose to participate in this survey, but don't feel comfortable submitting it via the internet, please send me an e-mail message. I will be happy to accommodate your participation in this survey over the phone or on paper through the postal mail.

Regardless of whether you choose to participate, you are welcome to a complete summary of my finings. To receive a summary, reply to this e-mail invitation. If you have any questions or concerns about participating, feel free to contact me anytime by e-mail at ebuchman@mix.wvu.edu, or by phone at (304) 283-9093.

Sincerely,

Eva M. Buchman

Graduate Student

Perley Isaac Reed School of Journalism

West Virginia University 


\section{Appendix 2: Survey Instrument}

Please answer the following questions with the most applicable answer. There are no right or wrong answers. I am only interested in your viewpoints about the use of user-generated content in television broadcasts.

1. Approximately how many minutes per day does your station run local news? (Enter approximate number of minutes in the spaces provided.)

\begin{tabular}{|l|l|l|}
\hline Weekdays & Weekends & Newscast Time of Day \\
\hline & & Morning \\
\hline & & Noon \\
\hline & & Evening \\
\hline
\end{tabular}

2. Approximately how many pieces of user-generated content (photos, videos, audio or ideas to generate stories provided by an amateur viewer) does the average news broadcast contain? (Enter approximate number of pieces in the spaces provided.)

\begin{tabular}{|l|l|l|}
\hline Weekdays & Weekends & Newscast Time of Day \\
\hline & & Morning \\
\hline & & Noon \\
\hline & & Evening \\
\hline
\end{tabular}

3. Does your television station currently have in place any type of formal, written policy that dictates how you decide to use or not use pieces of user-generated content (defined as: photos, videos, audio, or ideas used to generate stories provided by an amateur viewer)?
a) yes
b) no
c) not sure

3a) If yes, please describe it OR provide the link to that policy in the space provided: 
4. Why did your news station decide to make a formal, written policy that outlines how you decide to use or not use pieces of user-generated content? Choose all that apply.

a) To eliminate any potential credibility or validity issues

b) For consistency and to eliminate any questions about what is or isn't acceptable

c) With the shift in journalism going toward more active reporting citizens, we felt it was necessary.

d) We saw other stations developing similar policies, and we wanted to be up to par and set a standard for what is or isn't appropriate.

e) Other

4a) If other, please explain why your station decided to make a formal, written policy that outlines how you decide to use or not use pieces of user-generated content, like photos, videos, audio, and ideas to generate stories:

5. Does your television station currently have in place any type of informal policy (defined as: rules that are not written down, but that are instead implied and understood by all employees at a television news station regarding the use or non-use of user-generated content sent to a television news station by a viewer) that dictates how you decide to use or not use pieces of user-generated content (defined as: photos, videos, audio, or ideas used to generate stories provided by an amateur viewer)?
a) yes
b) no
c) not sure

5a) If yes, please describe that informal policy: 
6. By the definition of user-generated content that has been determined for the purpose of this research (photos, videos, audio, or ideas to generate stories provided by an amateur viewer), what type of user-generated content have you used at your station? Choose all that apply.

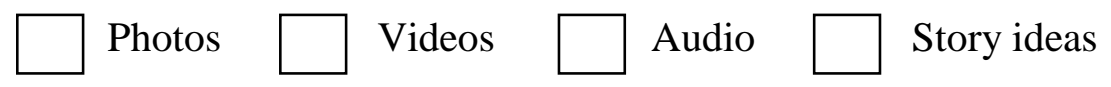

7. Which type of user-generated content (photos, videos, audio, or ideas to generate stories provided by an amateur viewer) does your station use most?
$\square$ P
Photos
$\square$ Videos

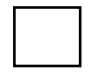
Audio

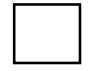
Story ideas

\section{Please indicate your level of agreement from strong disagree to strongly agree with the following statements about user-generated content (photos, videos, audio, or ideas to generate stories provided by an amateur viewer).}

8. Our television news station uses user-generated content because it helps to tell stories that the station can't necessarily cover because of time constraints.

\begin{tabular}{lllllll} 
Strongly disagree & & \multicolumn{4}{c}{ Strongly agree }
\end{tabular}

9. Our television news station uses user-generated content because it helps to tell stories that the station can't necessarily cover because of budget constraints.

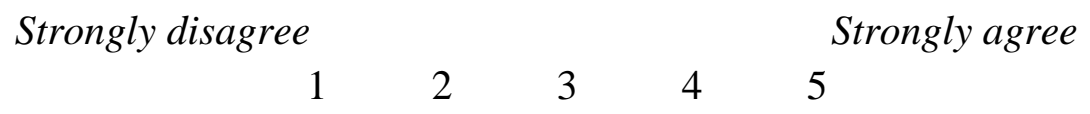

10. Our television news station uses user-generated content because it helps to tell stories that the station can't necessarily cover because of staff constraints.

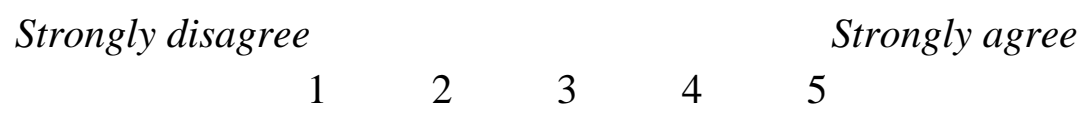

11. Our television news station uses user-generated content because it gives a more "personal perspective" to news.

Strongly disagree

Strongly agree

$\begin{array}{lllll}1 & 2 & 3 & 4 & 5\end{array}$


12. Our television news station uses user-generated content because it gives an "eye" into a breaking news situation until a professional crew can get to the scene.

$\begin{array}{rlllll}\text { Strongly disagree } & & & & & 5^{\text {Strongly agree }}\end{array}$

13. Our television news station uses user-generated content to develop a good (or better) relationship with the community.

$\begin{array}{lllllll}\text { Strongly disagree } & & & & & 5^{\text {Strongly agree }}\end{array}$

14. Our television news station uses user-generated content because we feel it enhances the quality of the broadcast.

\begin{tabular}{llllll} 
Strongly disagree & & & \multicolumn{1}{c}{$\begin{array}{c}\text { Strongly agree } \\
\end{array}$} & $\begin{array}{lllll}1 & 2 & 3 & 4 & 5\end{array}$
\end{tabular}

15. Our television news station uses user-generated content because it is more economical than paying more reporters to cover all the stories.

\begin{tabular}{llllll} 
Strongly disagree & & & & \multicolumn{3}{c}{$\begin{array}{c}\text { Strongly agree } \\
\end{array}$} & 1 & 2 & 3 & 4 & 5
\end{tabular}

16. Our television news station uses user-generated content so our trained reporters can focus on covering bigger, more important stories.

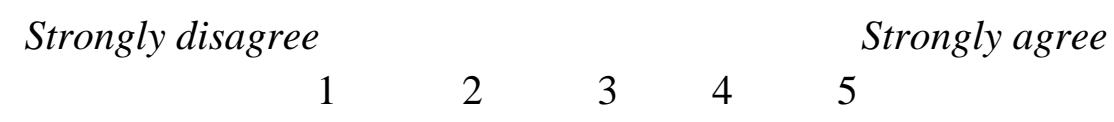

17. Our television news station uses user-generated content because it allows us to better connect with our viewers.

\begin{tabular}{rllllll} 
Strongly disagree & & & \multicolumn{3}{c}{ Strongly agree } \\
1 & 2 & 3 & 4 & 5
\end{tabular}

Please answer the following questions with the most applicable answer. There are no right or wrong answers. I am only interested in your viewpoints about the use of user-generated content in television broadcasts.

18. Does your news station encourage viewers to send in pieces of user-generated content, via a news broadcast, the web, face-to-face communication or on social media?
a) Yes
b) No 
$\rightarrow$ If you answered yes, please indicate how your station encourages viewers to send in pieces of user-generated content.

a) We have a designated place on our website where we encourage viewers to send us information regarding a story or event, or to send us photos, videos or audio.

b) We regularly require our reporters to use their work Twitter and Facebook accounts to encourage viewers to send in user-generated content.

c) We encourage our reporters to ask for information and pieces of user-generated content while they are reporting in the field.

d) We encourage our viewers to send in pieces of user-generated content during our news broadcasts.

e) Other (Please specify.)

$\rightarrow$ If you answered no, please indicate why your station does not encourage viewers to send in pieces of user-generated content.

a) We don't think user-generated content is important to our news broadcast.

b) Because our station has a policy against using user-generated content.

c) We don't encourage viewers to send in user-generated content, but if we receive any, we may or may not use it.

d) Other (Please specify.) 
19. If you don't use content provided to you by viewers, will your station take into consideration story ideas that are sent to the station by members of the community?

a) Yes, we think it is important to listen to what the members of the community feel is newsworthy.

b) Yes, because we want the communities that we represent to feel included in the news making process.

c) Not really, our station has a good idea of what is happening in communities and what needs reported on.

d) No, we feel it is strictly the job of our station to find and report on newsworthy events.

e) Other.

19a) If other, please explain why your station does or does not take into consideration story ideas that are sent to the station by members of the community:

For purposes of this research, user-generated content has been defined as: photos, videos, audio, or ideas to generate stories provided by amateur viewers. Please indicate your perceptions of user-generated content, in general, for each of the following questions.

20. Unprofessional

Professional

21. Unhelpful

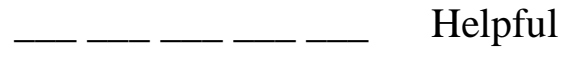

22. Bad

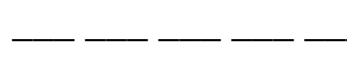

Good

23. Not trustworthy

Trustworthy

24. Unethical

Ethical

25. Mal Intentioned

Good Intentioned 
Now, I would like to obtain some demographic information about yourself and the television station where you are currently employed. Please answer the following questions.

26. How many years have you been employed at your current station?

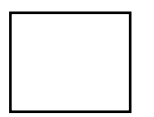

Enter number of years

27. How many years have you held your position of News Director/Executive Producer at your current station?

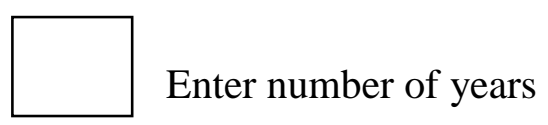

28. How many years have you worked in the television industry?

Enter number of years

Thank you for your time and participation in this study!

For questions or added input,

please contact me at ebuchman@mix.wvu.edu or 304-283-9093. 


\section{Appendix 3: Consent for web survey}

\section{W. WestVirginiaUniversity.}

Human Research Protocol Only Minimal Risk Consent Form Without HIPAA

\section{Only Minimal Risk Consent Information Form (without HIPAA)}

Principal Investigator

Department

Protocol Number

Study Title

Co-Investigator(s)

Sponsor (if any)
Rita Colistra, Ph.D.

P.I. Reed School of Journalism

62938

User-Generated Content and Television News

Eva Buchman

Not Applicable

\section{Contact Persons}

If you have any questions, concerns, or complaints about this research, you can contact Dr. Rita Colistra at (304) 2936793 or Eva Buchman at (304) 283-9093.

For information regarding your rights as a research subject, to discuss problems, concerns, or suggestions related to the research, to obtain information or offer input about the research, contact the Office of Research Integrity \& Compliance at (304) 293-7073.

In addition if you would like to discuss problems, concerns, have suggestions related to research, or would like to offer input about the research, contact the Office of Research Integrity and Compliance at 304-293-7073.

\section{Introduction}

You have been asked to participate in this research study, which has been explained to you by Eva Buchman. This study is being conducted by Eva Buchman in the School of Journalism at West Virginia University in accordance with the requirements to fulfill a master's degree in Journalism.

\section{Purpose(s) of the Study}

This study seeks to find what standards and procedures are used by television stations in selecting or rejecting usergenerated content for use in their television programs. Perceptions of user-generated content will also be gauged. This research will help both citizens and television news professionals understand the policies and/or practices of using or not using user-generated content in order to shed light on this newer tool in the media.

\section{Description of Procedures}

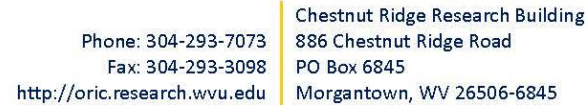

Phone: $304-293-7073$ http://oric. research.wvu.ed

\author{
Morgantown, WV 26506-6845
}

Pag $\mathrm{e} \mid \mathbf{1}$

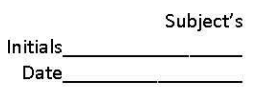




\section{Figure 3: Consent for web survey}

This study involves asking News Directors/Executive Producers at television news stations about the policies at their stations regarding the use or non-use of user-generated content in a television news broadcast. It will take approximately 10 minutes or less for you to complete. You will be asked to fill out a questionnaire regarding your news stations practices and/or policies regarding user-generated content and your use and perceptions of this type of content. You may quit the survey at any time.

\section{Discomforts}

There are no known or expected risks from participating in this study, except for the mild frustration associated with answering the questions.

\section{Alternatives}

You do not have to participate in this study. Alternative options for participation in the research include taking the survey over the phone or completing it by mail.

\section{Benefits}

You may not receive any direct benefit from this study. The knowledge gained from this study may eventually benefit others.

\section{Financial Considerations}

There are no special fees for participating in this study. Participants will not be paid.

\section{Confidentiality}

Any information that is obtained as a result of your participation in this research will be kept confidential. Every effort will be made to ensure that your privacy and confidentiality will be protected. Your name and contact information will only be used to track who has or has not responded so reminder messages can be sent. No information will be attributed to any specific individual. Results of each question will be compiled electronically by the Web survey program, and only I, Eva Buchman, and my thesis chair will have access to these data.

\section{Voluntary Participation}

Participation in this study is voluntary. You are free to withdraw your consent to participate in this study at any time.

Refusal to participate or withdrawal will not affect you in any way.

By clicking "next" and starting the survey, you are willingly consenting to participating in this research.

Phone: 304-293-7073 Fax: 304-293-3098 http://oric. research.wvu.ed
Chestnut Ridge Research Building

886 Chestnut Ridge Road

PO Box 6845

Morgantown, WV 26506-6845
Page 12

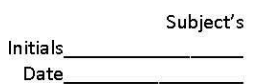




\section{Appendix 4: First E-mail Reminder Message}

$<<$ First_Name $>>$,

A few days ago, I sent you an e-mail message with a link to a survey regarding the use of usergenerated content and television broadcasts.

Your response is important because you are a key decision maker in selecting the news content that is broadcast. If you were in the process of filling out the survey but were interrupted, you can return to it and finish by following this link to the survey: <<Respondent-Specific_URL〉>

If you haven't had a chance to review the survey, I hope you will do so soon. It should take 10 minutes or less to complete. The information from the survey will help us to better understand what standards and procedures are used by television stations in selecting or rejecting usergenerated content for use in news broadcasts, as well as your general perceptions of this type of content. It will also help me complete me serve the profession that I love and complete my master's thesis!

Thank you for participating in the study of user-generated content and its use in television broadcasts. Please follow this link to the survey: $\langle<$ Respondent-Specific_URL $>$.

This is a research study. West Virginia University's Institutional Review Board (IRB) has acknowledgement of this study on file.

If you have any comments or questions, please feel free to contact me by e-mail at ebuchman@mix.wvu.edu or by telephone at (304) 283-9093. This is a research study. West Virginia University's Institutional Review Board (IRB) has acknowledgement of this study on file.

Sincerely,

Eva Buchman

Graduate Student

Perley Isaac Reed School of Journalism

West Virginia University 


\section{Appendix 5: Second/Final E-mail Reminder Message}

$<<$ First_Name >,

I am writing to ask for your help in an important research survey regarding the use of usergenerated content in television broadcasts. The survey should take 10 minutes or fewer to complete. This study is being conducted as part of my master's thesis research at the Perley Isaac Reed School of Journalism at West Virginia University. Dr. Rita Colistra is the committee chairperson for this research. West Virginia University's Institutional Review Board (IRB) has acknowledgement of this study on file. The survey can be found at: <<RespondentSpecific_URL〉>.

This research is important because it will help us to better understand and practices and/or policies at television stations regarding the use of user-generated content submitted by an amateur viewer, as well as to gauge perceptions of this type of content. Your response is critical to the study's success because you are a key decision maker regarding content on news broadcasts.

Again, the survey should take 10 minutes or fewer to complete. Your answers will be kept private and confidential. I guarantee that your responses will not be connected to you personally. The results of this project will be analyzed in various formats, but your answers will not be matched with you. Participation in this survey is voluntary, and you may choose to opt out at any time. However, I do hope that you will choose to participate, as your input will add value to this project. To participate, the survey can be found via this link: $\langle\langle$ Respondent-Specific_URL $\rangle$.

If you choose to participate in this survey, but don't feel comfortable submitting it via the internet, please send me an e-mail message. I will be happy to accommodate your participation in this survey over the phone or on paper through postal mail.

Regardless of whether you choose to participate, you are welcome to a complete summary of my findings. To receive a summary, reply to this e-mail. If you have any questions or concerns about participating, feel free to contact me anytime by e-mail at ebuchman@ mix.wvu.edu, or by phone at (304) 283-9093.

Sincerely,

Eva Buchman

Graduate Student

Perley Isaac Reed School of Journalism

West Virginia University 


\section{Appendix 6: Link between Research and Survey Questions}

Table 1: Link between Research and Survey Questions

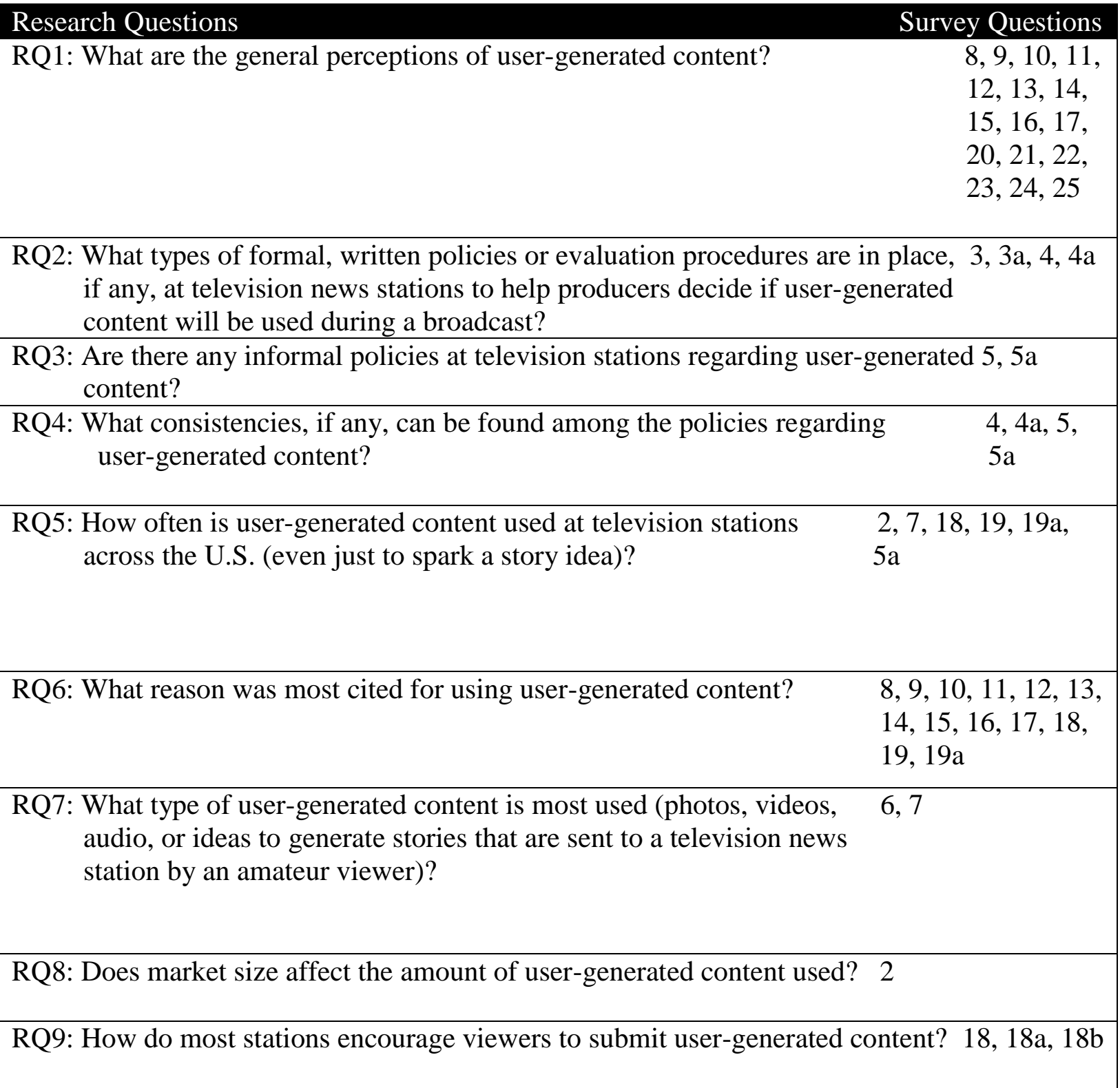


Appendix 7: Figure 1

Figure 1: Do you have a formal, written policy in place?

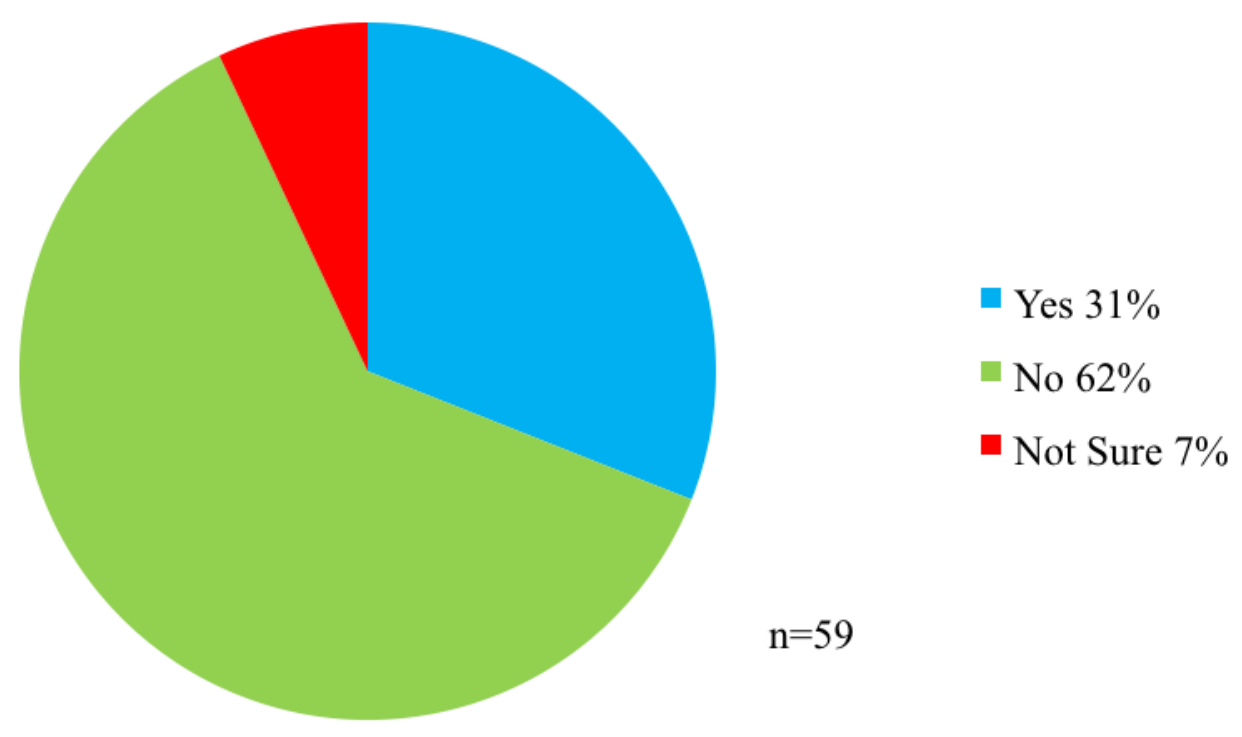

Appendix 8: Figure 2

Figure 2: Does your station have an informal policy in place?

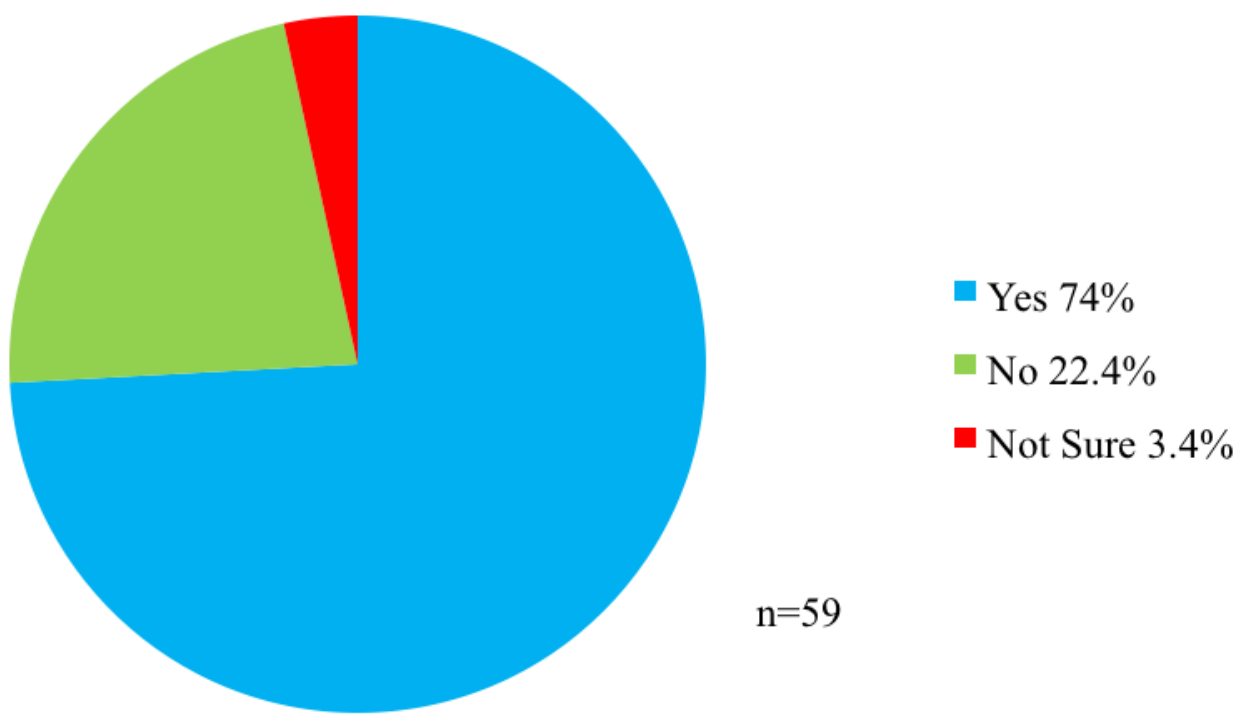


Appendix 9: Common themes of formal policies

Table 2: Common themes of formal policies

Common themes of formal, written policies

- Content must be vetted by news director/another professional journalist before it can reach the web or the broadcast

- Providers of content must give up their rights to content

- Content must be credited to the viewer

Appendix 10: Frequency of mentions (Formal policies)

Table 3: Frequency of mentions

Frequency of mentions (Formal policies)

\begin{tabular}{|l|c|}
\hline $\begin{array}{l}\text { Reasons } \\
\text { mentioned }\end{array}$ & \% (count) \\
\hline $\begin{array}{l}\text { Content must be } \\
\text { vetted before use }\end{array}$ & $28.5(4)$ \\
\hline $\begin{array}{l}\text { Content creator } \\
\text { must give up } \\
\text { rights to content } \\
\text { after submission }\end{array}$ & $21.4(3)$ \\
\hline $\begin{array}{l}\text { Content must be } \\
\text { credited/sourced } \\
\text { before use }\end{array}$ & $14.2(2)$ \\
\hline
\end{tabular}


Appendix 11: Common themes of informal policies

Table 4: Common themes of informal policies

\section{Common themes of informal policies}

- All content must be evaluated before use

- All content must be sourced, said content should not be used until the source can be properly identified

- Generally, if there is a question or concern, content will not be used

Appendix 12: Frequency of mentions (Informal policies)

Table 5: Frequency of mentions

\begin{tabular}{|l|c|}
\hline \multicolumn{2}{|l|}{ Frequency of mentions (Informal policies) } \\
\hline $\begin{array}{l}\text { Reasons } \\
\text { mentioned }\end{array}$ & \% (count) \\
\hline $\begin{array}{l}\text { Content must be } \\
\text { evaluated before } \\
\text { use }\end{array}$ & $35.2(12)$ \\
\hline $\begin{array}{l}\text { Content must be } \\
\text { sourced before use }\end{array}$ & $35.2(12)$ \\
\hline $\begin{array}{l}\text { If there is a } \\
\text { concern regarding } \\
\text { its use, it will not } \\
\text { be used }\end{array}$ & 11.7 (4) \\
\hline
\end{tabular}


Appendix 13: How often is user-generated content used at television stations across the U.S. (even just to spark a story idea?)

Table 6: How often is user-generated content used at television stations across the U.S. (even just to spark a story idea?)

\begin{tabular}{|l|l|l|l|}
\hline \multicolumn{1}{|c|}{ Weekdays } & Weekends & $\begin{array}{l}\text { Total means } \\
\text { and standard } \\
\text { deviations }\end{array}$ \\
\hline Mean $=3.28$ & Mean $=1.35$ & Morning & Mean $=4.79$ \\
SD $=4.064$ & SD $=3.236$ & & SD $=7.14$ \\
\hline Mean $=1.57$ & Mean $=.49$ & Afternoon & Mean $=1.82$ \\
SD $=3.188$ & SD $=1.295$ & & SD $=3.29$ \\
\hline Mean $=2.42$ & Mean $=2.00$ & Evening & Mean $=4.57$ \\
SD $=2.140$ & SD= 2.096 & & SD $=4.21$ \\
\hline Mean $=7.54$ & Mean $=3.26$ & & $\begin{array}{l}\text { Total means } \\
\text { and standard } \\
\text { deviations }\end{array}$ \\
\hline SD $=9.26$ & SD $=3.66$ & & \\
\hline
\end{tabular}




\section{Appendix 14: Table 7}

Table 7: What reason was most cited for using user-generated content?

\begin{tabular}{|l|l|l|l|l|l|l|}
\hline \multicolumn{6}{|l|}{ What reason was most cited for using user-generated content? } \\
\hline $\begin{array}{l}\text { Reasons for } \\
\text { using user- } \\
\text { generated } \\
\text { content }\end{array}$ & $\begin{array}{l}\text { Strongly } \\
\text { disagree }\end{array}$ & Disagree & $\begin{array}{l}\text { Neither agree } \\
\text { nor disagree }\end{array}$ & Agree & $\begin{array}{l}\text { Strongly } \\
\text { agree }\end{array}$ & Mean (SD) \\
\hline Time constraints & $5.4(3)$ & $23.2(13)$ & $8.9(5)$ & $41.1(23)$ & $21.4(12)$ & $3.50(1.221)$ \\
\hline $\begin{array}{l}\text { Budget } \\
\text { constraints }\end{array}$ & $14(8)$ & $36.8(21)$ & $21.1(12)$ & $19.3(11)$ & $8.8(5)$ & $2.72(1.192)$ \\
\hline $\begin{array}{l}\text { Staff constraints } \\
\text { Personal } \\
\text { perspective }\end{array}$ & $7.1(4)$ & $16.1(9)$ & $14.3(8)$ & $46.4(26)$ & $16.1(9)$ & $3.48(1.160)$ \\
\hline $\begin{array}{l}\text { Eye to breaking } \\
\text { news }\end{array}$ & $1.8(1)$ & $3.6(2)$ & $5.4(3)$ & $46.4(26)$ & $42.9(24)$ & $4.25(.858)$ \\
\hline $\begin{array}{l}\text { Better } \\
\text { relationship } \\
\text { with viewers }\end{array}$ & $0(0)$ & $1.8(1)$ & $26.8(15)$ & $50(28)$ & $21.4(12)$ & $3.91(.745)$ \\
\hline $\begin{array}{l}\text { Quality of } \\
\text { broadcast }\end{array}$ & $0(0)$ & $5.4(3)$ & $21.4(12)$ & $50(28)$ & $23.2(13)$ & $3.91(.815)$ \\
\hline $\begin{array}{l}\text { More } \\
\text { economical }\end{array}$ & $32.1(18)$ & $46.4(26)$ & $12.5(7)$ & $7.1(4)$ & $1.8(1)$ & $2.00(.953)$ \\
\hline $\begin{array}{l}\text { Focus on bigger } \\
\text { stories }\end{array}$ & $10.7(6)$ & $51.8(29)$ & $25(14)$ & $12.5(7)$ & $0(0)$ & $2.39(.846)$ \\
\hline $\begin{array}{l}\text { Better connect } \\
\text { with viewers }\end{array}$ & $0(0)$ & $1.8(1)$ & $19.6(11)$ & $50(28)$ & $28.6(16)$ & $4.05(.749)$ \\
\hline
\end{tabular}

$\mathrm{n}=59$ 
Appendix 15: Figure 3

Figure 3: What type of user-generated content is used most?

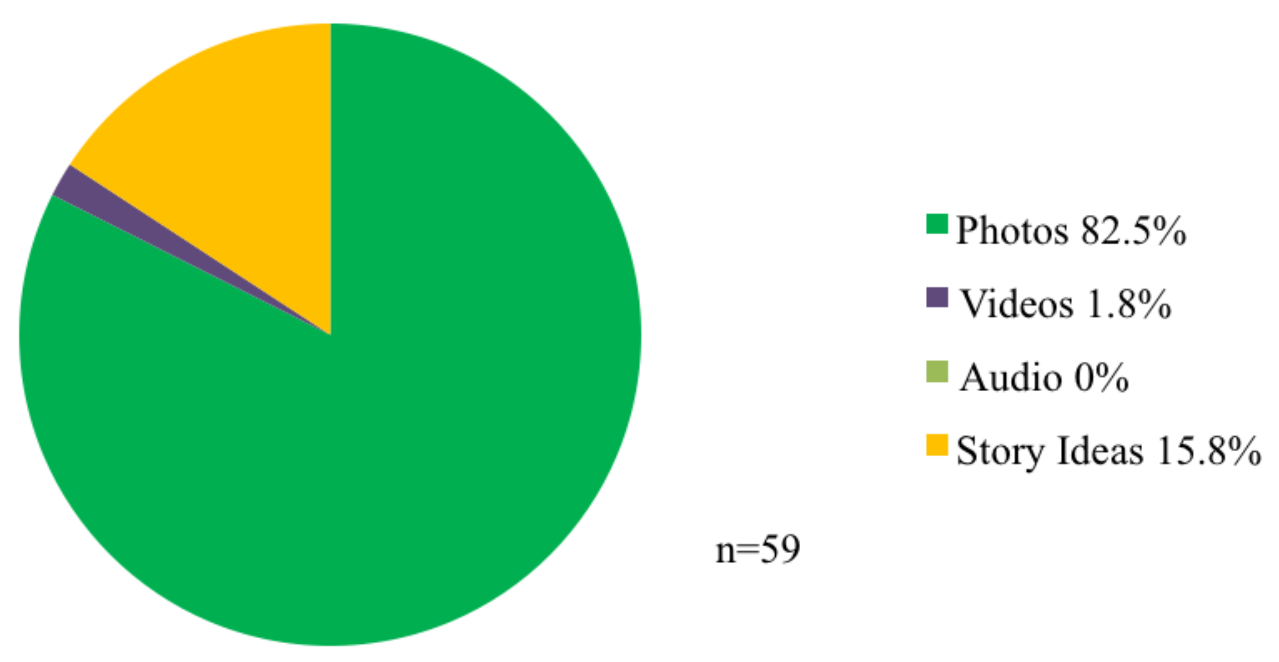

Appendix 16: Figure 4

Figure 4: Does your station encourage viewers to send in pieces of user-generated content?

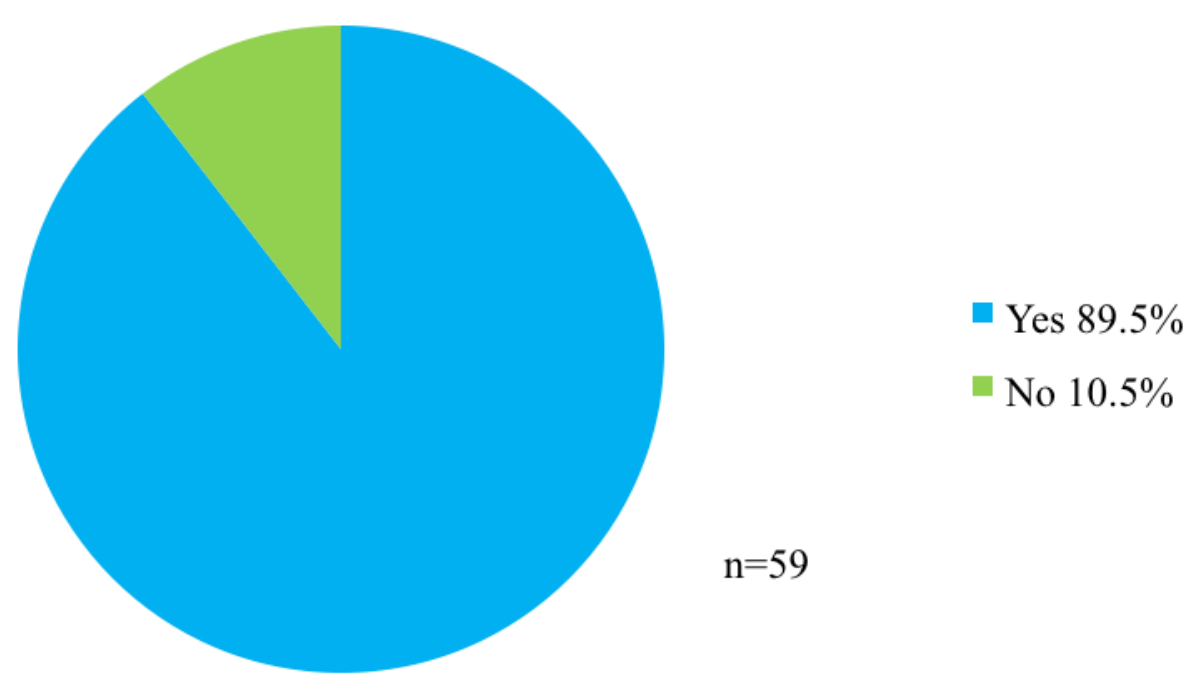




\section{Appendix 17: Table 8}

Table 8: How does your station encourage viewers to submit pieces of user-generated content?

How does your station encourage viewers to submit pieces of user-generated content?

\begin{tabular}{|l|c|c|}
\hline $\begin{array}{l}\text { We have a designated place on our website where we } \\
\text { encourage viewers to send us information regarding a } \\
\text { story or event, or to send us photos, videos, or audio. }\end{array}$ & 25 & Prequency \\
\hline $\begin{array}{l}\text { We regularly require our reporters to use their work } \\
\text { Twitter and Facebook accounts to encourage viewers to } \\
\text { send in user-generated content. }\end{array}$ & $16 \%$ \\
\hline $\begin{array}{l}\text { We encourage our reporters to ask for information and } \\
\text { pieces of user-generated content while they are } \\
\text { reporting in the field. }\end{array}$ & 13 & $27.1 \%$ \\
\hline $\begin{array}{l}\text { We encourage our viewers to send in pieces of user- } \\
\text { generated content during our news broadcasts. }\end{array}$ & 28 & $22 \%$ \\
\hline
\end{tabular}

$\mathrm{n}=59$ 


\section{Appendix 18: Table 9}

\section{Table 9: Summary of key findings}

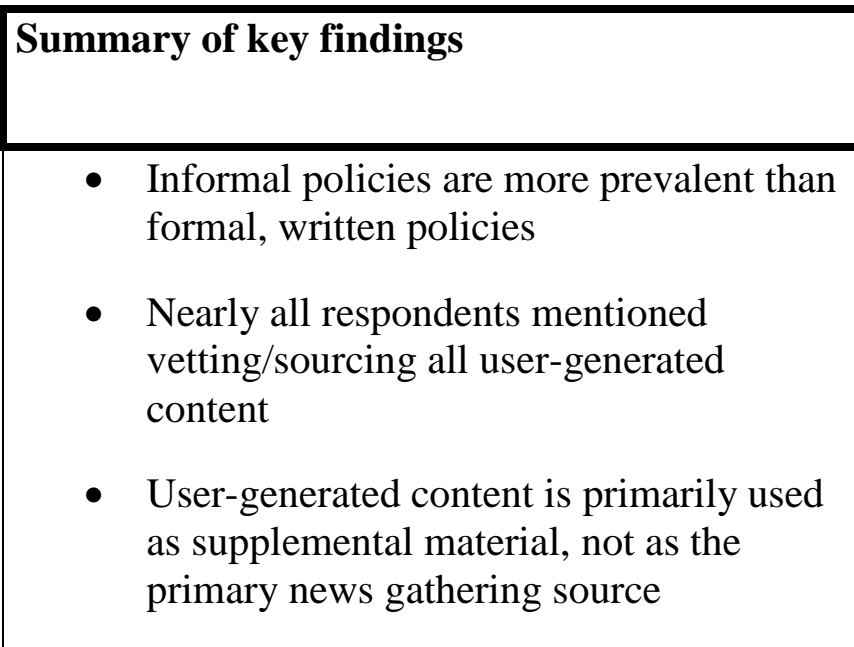




\section{REFERENCES}

Beaudry, A. E. (1996). The civic role in public journalism. National Civic Review, 26-28.

Bentley, C., Hamman, B., Ibold, H., Littau, J., \& Meyer, H. (2006). Sense of Community as a driver for citizen journalism. Civic and Citizen Journalism Interest Group AEJMC 2006 Annual Convention.

The Benton Foundation. 2011. April 21, 2013. Accessible at: http://benton.org/node/65435

Berkowitz, D. (1990). TV News Sources and News Channels: A study in Agenda-Building. Journalism Quarterly, 64, (2), 508-513.

Berkowitz, D. (1997). Social meanings of news. Thousand Oaks, Calif.,: SAGE Publications, Inc.

Black, J. (Ed.) (1997). Mixed News: The public/civic/communitarian journalism debate. Mahwah, N.J.: Lawrence Erlbaum Associates.

Breed, W. (1955). Social Control in the Newsroom: A Functional Analysis. Social Forces, $33,(4), 326-335$.

Brown, F. (2005). 'Citizen' journalism is not professional journalism. Quill Magazine, 93, (6), 42.

Clark, R. P. (2009). Who is the fifth estate and what is its role in journalism's future? The Poynter Institute. http://www.poynter.org/latest-news/top-stories/95483/who-is-the-fifthestate-and-what-is-its-role-in-journalisms-future/

Colistra, R. (2010). No Bark and No Bite: When Addressing Ethical Code Violators, is the Society of Professional Journalists (SPJ) Mute and Toothless? The International Journal Of Interdisciplinary Social Sciences, 5, (4).

De Keyser, J. \& Raeymaeckers, K. (2012). The printed rise of the common man. Journalism Studies, 13 (5-6), 825-835.

Dillman, D. A. (2000). Mail and Internet Surveys: The Tailored Design Method. New York, N.Y.: John Wiley \& Sons, Inc.

Feighery, G. (2011). Conversation and credibility: Broadening journalism criticism through public engagement. Journal of Mass Media Ethics, 26, 158-175.

Fernando, A. (2008). Citizen-powered journalism fills a void. Communication World, 25 (1), 89.

Gillmor, D. (2004). We the media: the rise of citizen journalists. National Civic Review, 58-63. 
Habermas, J. ([1962] 2000). The structural transformation of the public sphere: An inquiry into a category of bourgeois society. MA: Cambridge: The MIT Press.

Hill, K. (2012, Dec. 17). Blaming the wrong Lanza: How media got it wrong in Newtown. Forbes. Retrieved March 20, 2014, from: http://www.forbes.com/sites/kashmirhill/ 2012/12/17/blaming-the-wrong-lanza-how-media-got-it-wrong-in-newtown/

Ibelema, M., \& Powell, L. (Winter 2001). Cable Television News Viewed As Most Credible. Newspaper Research Journal, 22 (1), 41-52.

Johnson, K. A., \& Wiedenbeck, S. (2009) Enhancing perceived credibility of citizen journalism web sites. Journalism and Mass Communication Quarterly, 86 (2), 332-348.

King, L. (2012). Vetting citizen Journalism. Nieman Reports.

Lauterer, J. (2000). Community Journalism: The Personal Approach. Ames, Iowa: Iowa State University Press.

Lewin, K. (1947). Frontiers in Group Dynamics: II. Channels of Group Life; Social Planning and Action Research. Human Relations, 1. 143-153.

Lewis, J. (2006). News and the empowerment of citizens. European Journal of Cultural Studies, 9 (3), 303-319.

Lim, J. (2011). Intermedia Agenda Setting and News Discourse: A strategic responses model for A competitor's breaking stories. Journalism Practice, 5, (2), 227-244.

MacIntyre, A. (1996). A short history of ethics. Notre Dame, IN.: Routledge.

Madrigal, A. (2013, April 13). \#BostonBombing: The Anatomy of a Misinformation Disaster. The Atlantic. Retrieved March 20, 2014, from: http://www.theatlantic.com/technology/ archive/2013/04/-bostonbombing-the-anatomy-of-a-misinformation-disaster/275155/

Marshall, J. (2005). Citizen journalism continues to surge: new technology blurring the lines between journalists and their audience. Quill Magazine, 14-16.

Mayer, J. (2011). Engaging communities: Content and conversation. Nieman Reports, 12-14.

McCombs, M., \& Shaw, D. L. (1972). The agenda-setting function of mass media. Public Opinion Quarterly, 36, 176-187.

Miller, R. (2008). The new journalism: It's audience participation time. EContent, 31 (6), 30-34.

The Nielsen Company. (2012, Sept. 22). Local Television Market Universe Estimates. Nielsen. Retrieved November 13, 2013, from: http://www.tvb.org/media/file/TVB_Market_Profiles Nielsen_Household_DMA_Ranks2.pdf 
Nip, J. (2006). Exploring the second phase of public journalism. Journalism Studies, 7 (2), 212236.

O'Reilly. (2011, Jan. 13). Reading O'Reilly: What is Web 2.0. Clatter from the Byte Kitchen. Retrieved March 18, 2014, from: http://thebytekitchen.com/2011/01/13/readingoreilly-what-is-web-2-0-2005/

Pew Research Center. "In changing news landscape, even television is vulnerable: Trends in news consumption: 1991- 2012.” September 27, 2012. April 21, 2013. Accessible at: http://www.people-press.org/2012/09/27/section-2-online-and-digital-news-2/

Pew Research Center. "In changing news landscape, even television is vulnerable: Trends in news consumption: 1991- 2012: Section 1: Watching, reading, and listening to the news." September 27, 2012. April 21, 2013. Accessible at: http://www.people-press.org/2012/09/27/ section-1-watching-reading-and-listening-to-the-news-3/

Schaefer, D., \& Dillman, D. A. (1998). Development of a standard e-mail methodology: Results of an experiment. Public Opinion Quarterly, 62, 378-397.

Shirky, C. (2008). Here Comes Everybody. New York, N.Y.: Penguin Books.

Shoemaker, P. J., \& Reese, S. D. (1996). Mediating the Message: Theories of Influence on Mass Media Content, Second Edition. White Plains, N.Y.: Longman Publishers USA.

Sites, W. (1998). Communitarian theory and community development in the United States. Community Development Journal, 33 (1), 57-65.

Society of Professional Journalists. 1996- 2013. April 21, 2013. Accessible at: www.spj.org/ mission.asp

Stanglin, D. (2013, April 25). Student wrongly tied to Boston bombings found dead. Retrieved March 20, 2014, from: archive/2013/04/-bostonbombing-the-anatomy-of-amisinformation-disaster/275155/

University of Texas at Austin. 2011, Sept. 21. November 20, 2013. Accessible at: https://www. utexas.edu/academic/ctl/assessment/iar/teaching/gather/method/survey-Response.php

Voakes, P. S. (2004). A brief history of public journalism. National Civic Review, 25-35.

Wahl-Jorgensen, K., Williams, A. and Wardle, C. (2010), 'Audience views on user-generated content: exploring the value of news from the bottom up', Northern Lights 8, pp. 177-1 